\title{
Effect of Educational Interventions based on Health Belief Model (HBM) on Puberty Health Behaviors in Tehran's Female Elementary Students, 2019
}

\begin{abstract}
Background and Objective: Several studies indicate low knowledge and poor performance of girls in puberty and menstruation. Puberty complications are easily preventable. Consequently, present study mainly aims to determine the effect of educational interventions based on Health Belief Model (HBM) on puberty health behaviors in Tehran's female elementary students, 2019.

Material and Method: This study was quasi-experimental using random sampling methods for selecting among female elementary students in Tehran, District 14, 2019. Data collection was performed through a designed questionnaire based on HBM. The questionnaire's reliability and validity were verified. Students filled out the questionnaire prior to the intervention. Educational interventions were performed for intervention group in three 45 -minute sessions. Two groups filled out questionnaires a month after intervention. The data was analyzed through SPSS v.24 using k-square, Independent t, paired t, Anova variance and Ancova covariance.

Results: Findings showed demographic variables were not significantly different in two groups $(p>0.05)$ except in their father's occupation, menstruation beginning's awareness and age. In the case group after intervention, mean knowledge, average of perceived susceptibility, average of perceived severity, average of self-efficacy, average of perceived benefits and average behavior increased and average of perceived barriers decreased. They were significantly different in the intervention group ( $p<0.05$ ), except in perceived benefits and self-efficacy, but not in the control group ( $p>0.05)$. The results of Ancova covariance test showed that educational intervention based on HBM had a significant effect on students' health during puberty $(\mathrm{P}<0.05)$.

Conclusion: The educational intervention based on HBM could change the puberty health awareness and behavior.

Keywords: Physical Puberty, Health Belief Model, Health Behavior, Female Elementary Students.

Paper Type: Research Article.
\end{abstract}

Citation (Vancouver): Kazemi Z, Shojaeezadeh D, Jalili Z. Effect of Educational Interventions based on Health Belief Model (HBM) on Puberty Health Behaviors in Tehran's Female Elementary Students, 2019. Iran J Health Educ Health Promot. Spring 2020;8(2): 142-159. [Persian]x

- Citation (APA): Kazemi Z., Shojaeezadeh D., Jalili Z., Effect of Educational Interventions based on Health Belief Model (HBM) on Puberty Health Behaviors in Tehran's Female Elementary Students, 2019. (Summer 2020). Conc... . Iranian Journal of Health Education \& Health Promotion., 8(2), 142-159. [Persian]

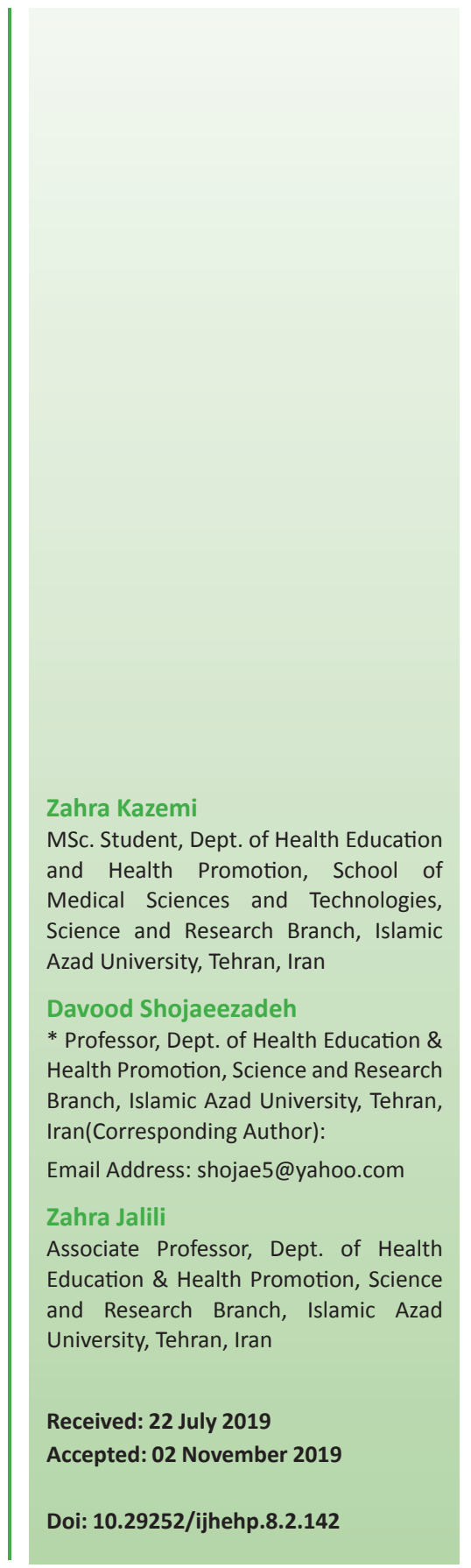




\section{تأثير مداخله آموزشى مبتنى بر مدل اعتقاد بهداشتى در رفتارهاى بهداشتى دوران بلوغ ه.

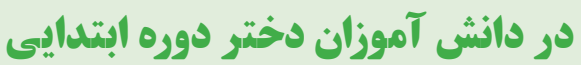

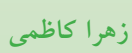

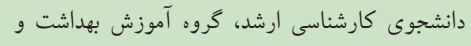

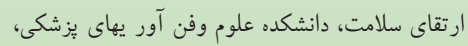

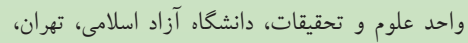

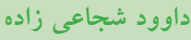

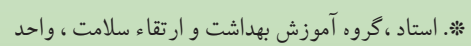
علوم و تحقيقات ، دانشكاء آزاد اسلامى، تهران، ايران. (نو يسنده مسئول) shojae5@yahoo.com

زهر ا جليلى rا.دانشيار، گروه آموزش بهداشت و ارتقاى سلامت،

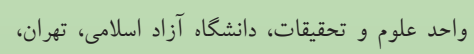
تاريخ يذيرش: |

\section{جكيده}

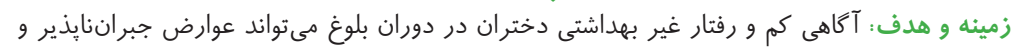

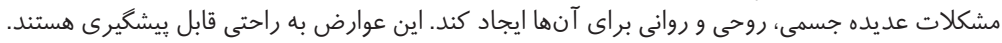

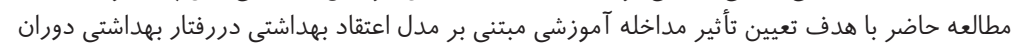

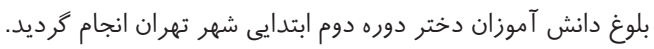

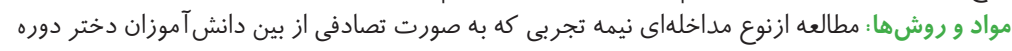

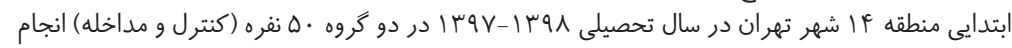

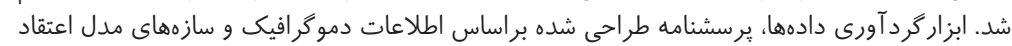

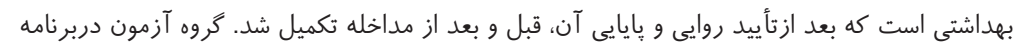

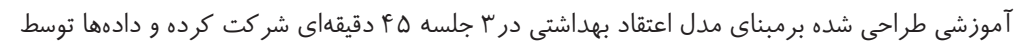

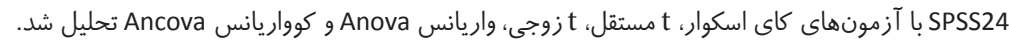

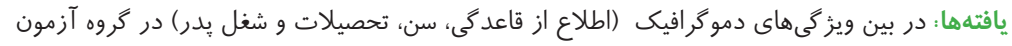

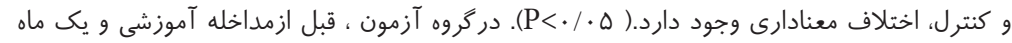

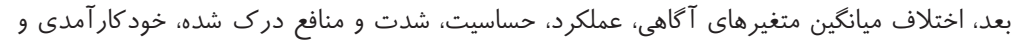

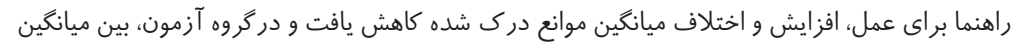

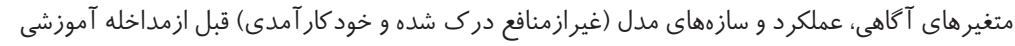

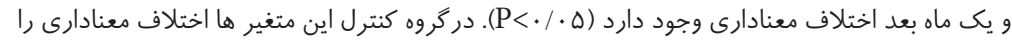

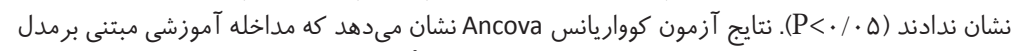

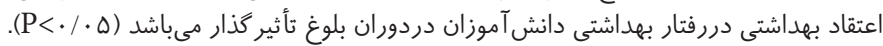

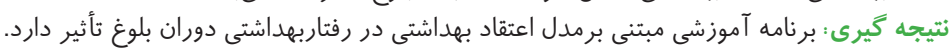

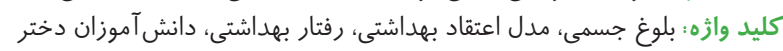
نوع مقاله : مطالعه يزوهشى.

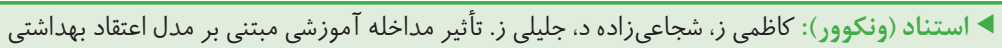

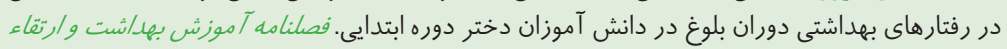

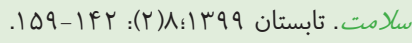

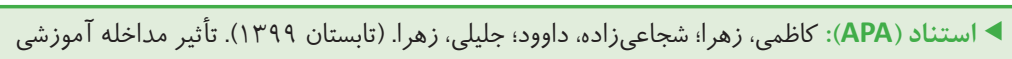

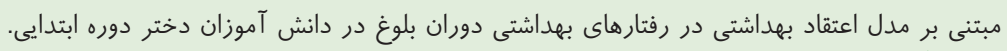


دوران بلوغ و كيفيت گذر از آن در دختران حائز اهميت بوده

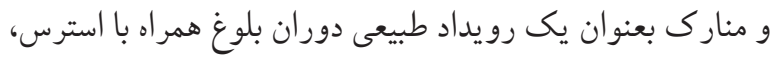
احساسات منفى جون شرم، ترس و اضطر اب است. اكثر دختران آكاهى مناسب درباره تغييرات جسمى و روانى دوران بلوغ نداش نداشته،

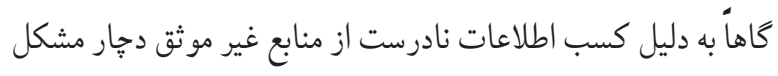

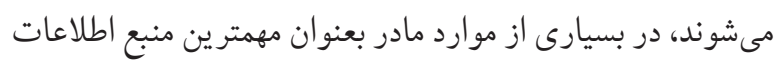

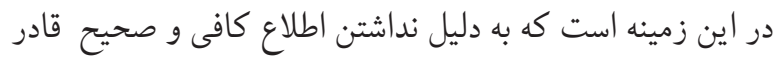

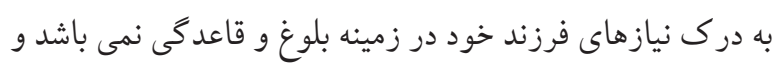

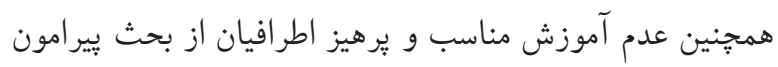

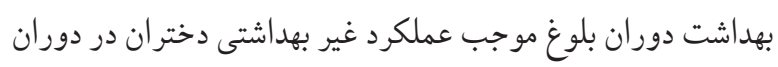

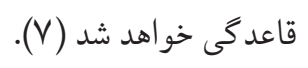

مطالعات در كشورما حاكى از ميزان آكاهى و عملكرد نامناسب

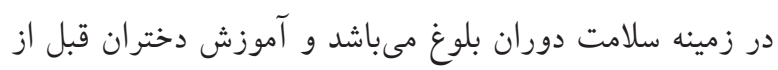
بلوغ جهت بالا بردن آكاهى و كاهش اضطراب و و عملكرد بهتر

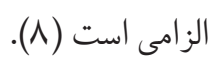

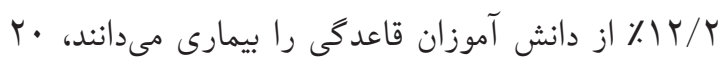

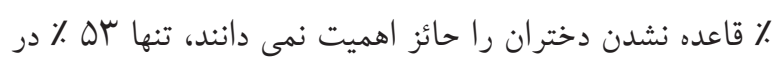

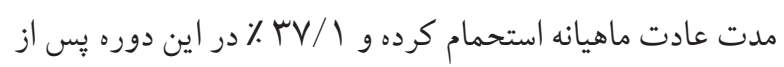

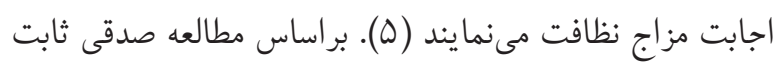

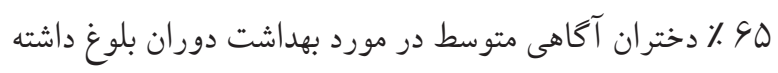

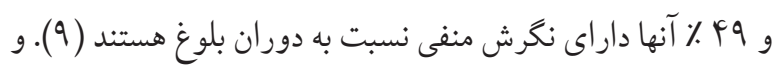

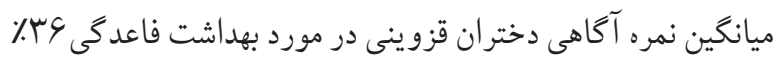

$$
\text { بوده است (·) بانكين (1). }
$$

ير داختن به بهداشت اين كَروه از جامعه نه فقط براى خود آنها،

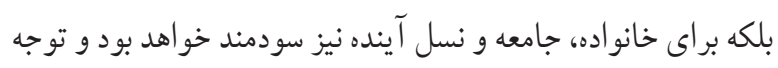

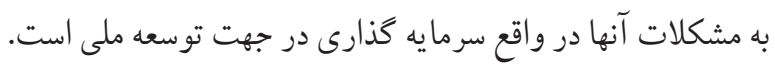

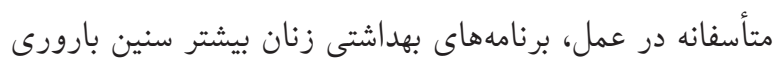

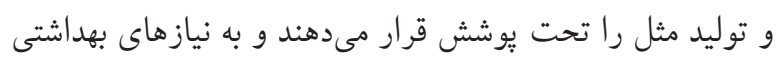

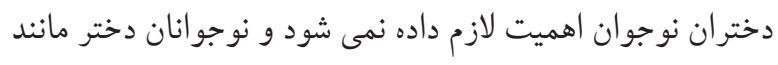

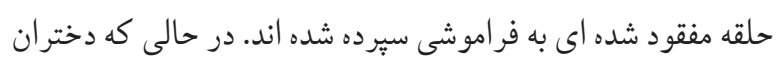

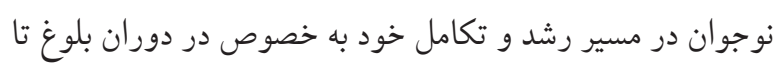

بلوغ مرحله اى بحرانى از رشد و نمو و دوره انتقال از كودكى به البه

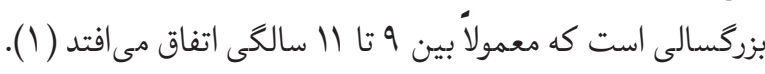
طبق اساسنامه سازمان جهانى بهداشت (WHO) سلامت به عنوان ارزشى فردى و اجتماعى محسوب مى شود و از ديدكاه ملل و

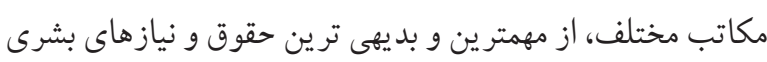

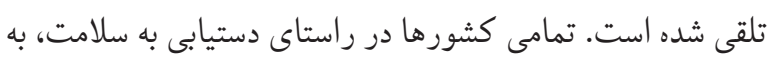
همه كَروهاى مختلف جامعه توجه مى كنند. از ميان اين كروهيا،

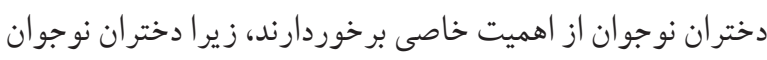

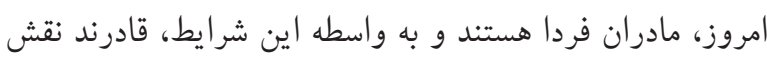

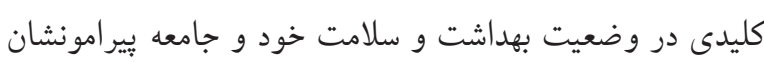
را ايفا نمايند (Y). اين امر خصوصاً از كنفرانس بين المللى جمعيت و توسعه قاهره

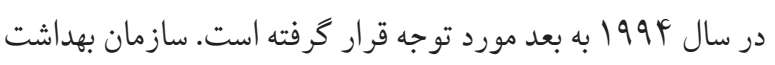

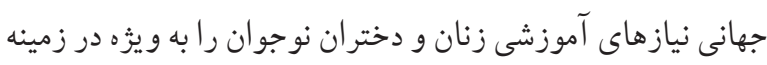

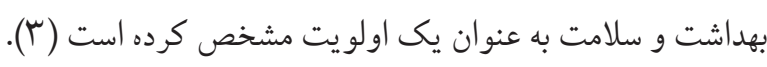
بر اساس تعريف سازمان بهداشت جهانى، اين دوران سر آغاز

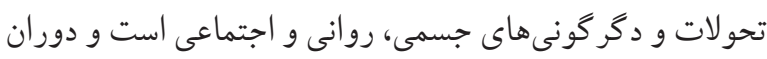

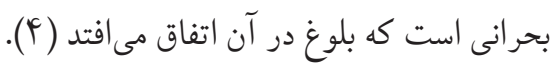

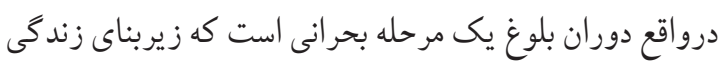

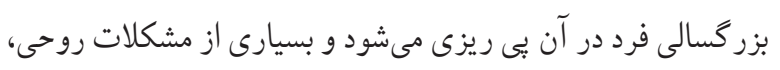

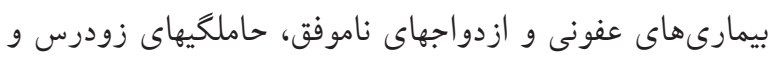

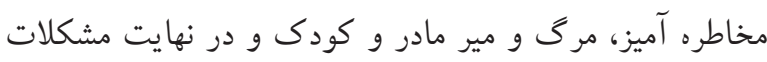
عديده جسمى، روحى و روانى مادران ريشه در اين دوران دارد، مدركا

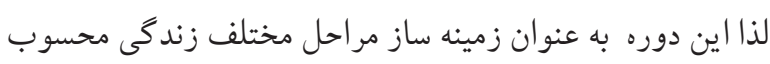

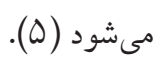

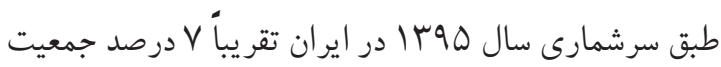

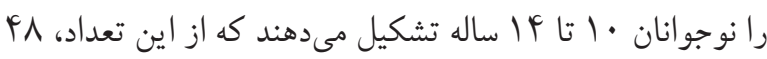

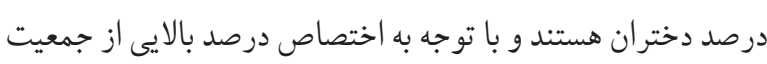

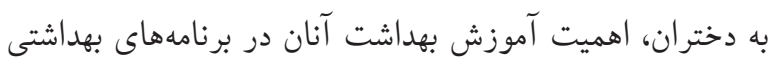
كاملاً محسوس مى باشد (9). 
مدل، فرد زمانى رفتار بهداشتى را اتخاذ مى كند كه عوامل زير بر او تاثير بخذارند: إ- حساسيت درك شده: درك و اعتقاد به اينكه در معرض خطر آسيب هستند. Y- شدت درك شده: درك و اعتقاد به اينكه اين مشكل بهداشتى جدى است و مى تواند منجر به نتايج

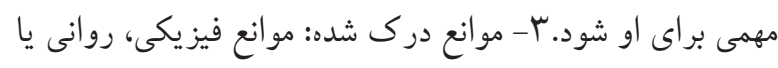
مالى و غيره كه در مقابل شخص، به منظور اتخاذ رفتار بهداشتى قرار

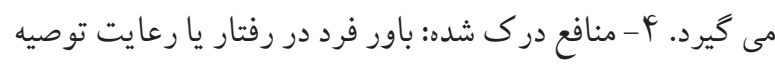
هايى است كه سبب كاهش شدت و عو ارض ناشى از آن آن مىشود.

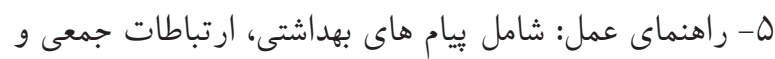
افر اد مورد قبول فرد نظير بز شكان، رهبران سياسى و مذهبى و نيز بيز

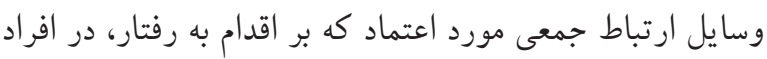

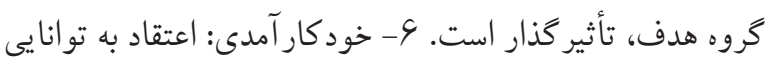
خود براى انجام موفقيت آميز كار(سا).

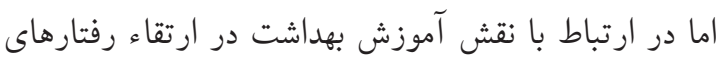

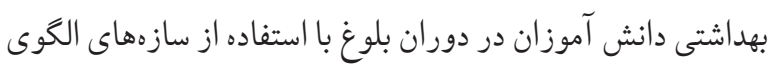

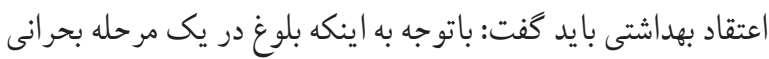

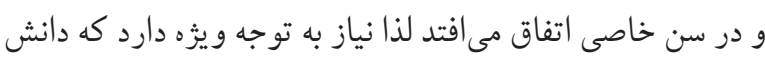
آموز حساس شده (حساسيت درى شده)، بداند كه عوارض عد عدم رعايت بهداشت در دوران بلوغ جيست؟ (شدت درى شد شده)، بتواند منافع انجام رفتار بهداشتى رادرى كند و موانع موجود براى انجام

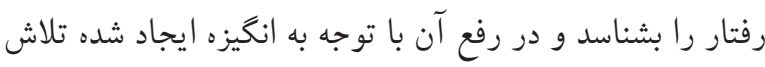

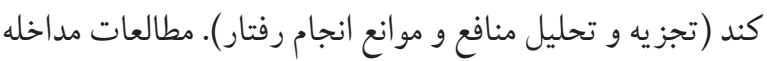

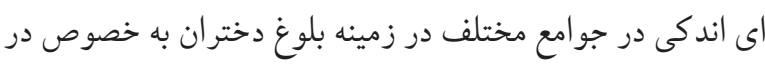

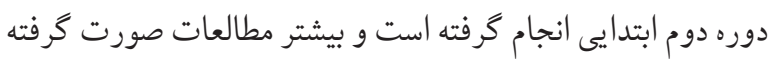
به دوره اول و دوم متوسطه يعنى زمانى كه جند سال از دوره بلوغ

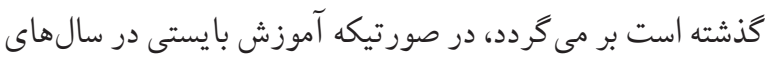

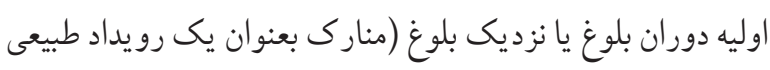

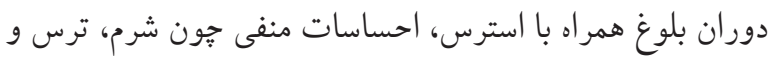

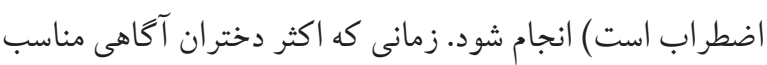
درباره تغييرات جسمى و روانى دوران بلوغ نداشته، كاهاً به دليل

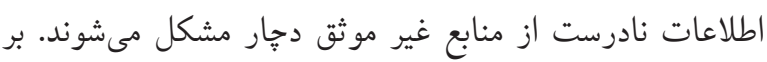

ازدواج و بعد از آن در معرض مشكلات جسمى، روانى و اجتماعى بسيار قرار مى گيرند. با اين وجود هنوز در برخى از جوامع دختران،

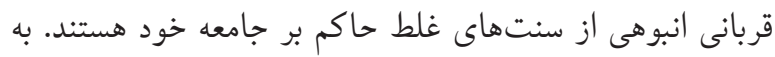
طورى كه به بهداشت، تغذيه و آموزش آنها در مقايسه با بِ بسران

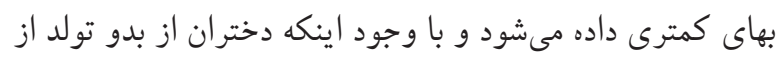

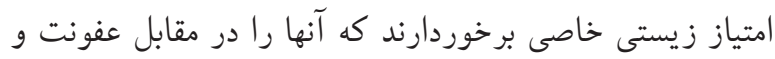

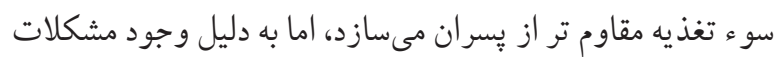

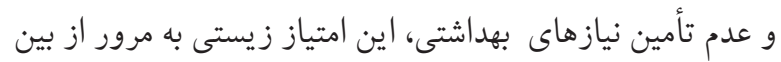

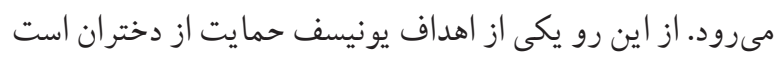

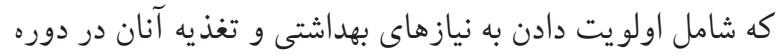
نوجوانى مى باشد (11). (11) عوارض و مشكلات دوران بلوغ به راحتى قابل بيشكيرى هستند و آموزش بهداشت مهمترين و اساسى ترين كام در جهت رفع مشكلات اين دوران مىباشد. اين آموزش بايستى جهت آكاه

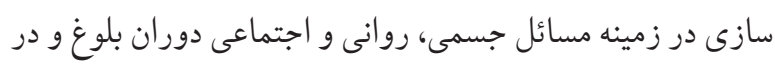

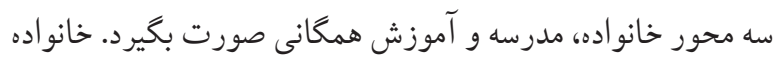

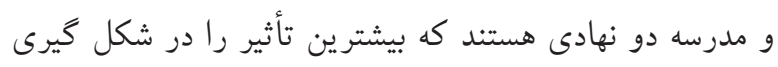

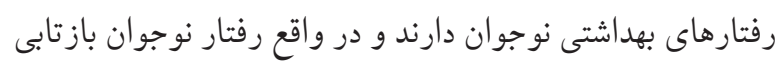

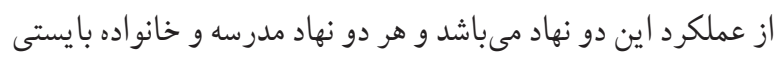
در آموزش مسائل بلوغ به نوجوانان سهيم باشند (T) (I ).

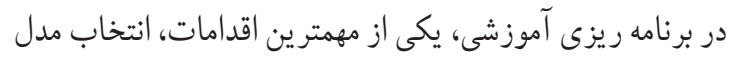

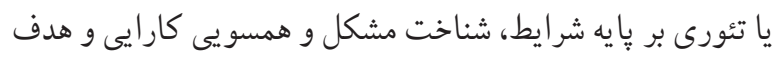

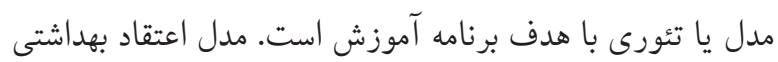

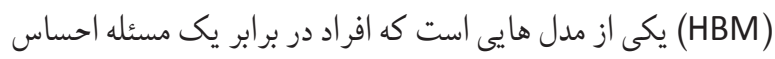
خطر نموده (حساسيت درك شده) سيس عمق خطر و جدى بودن

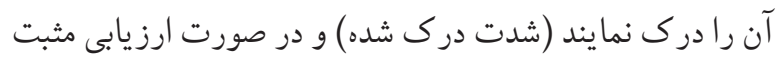
منافع رفتار بيشخيرى كننده و نبود موانع جدى نسبت به اتخاذ رفتار

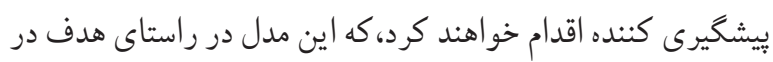
اين مطالعه مورد استفاده قرار خرفته است، به طورى كه از اين مدل حدل در آموزش كروههاى ثيزوهش ديكرى نيز در جهت كاهش يك مورد آسيب

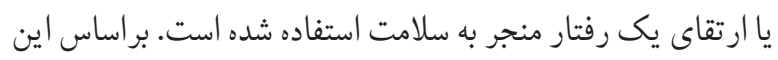


قسمت اول آن خصوصيات دمو گرافيك (سن، جندمين فرزند، مدرك تحصيلى پِدر ومادر، تعداد خواهر، و .... ) را شامل مىشد.

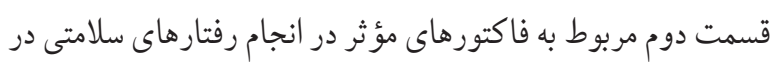
جهت بهداشت دوران بلوغ مثل سنجش آكاهى مى باشد. قسمت سوم

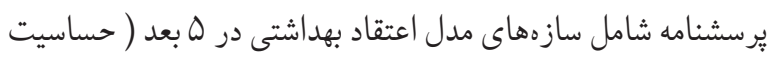

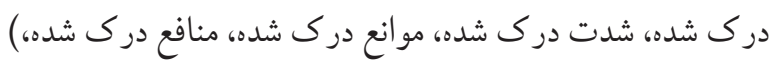
كه با مقياس ليكرت ه رتبه اى قابل باسخ و سنجش بودند.و سازه

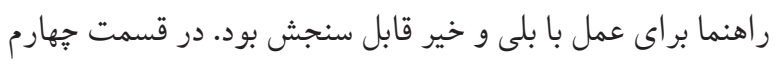

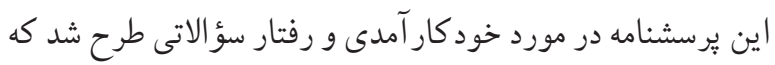

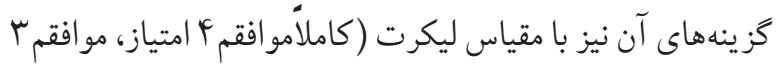

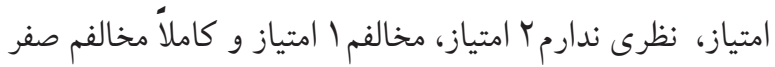

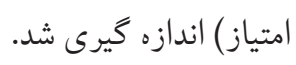

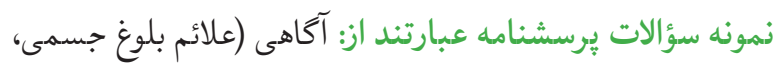
مدت خونريزى طبيعى و...)، حساسيت درك شده (من هـم مانند

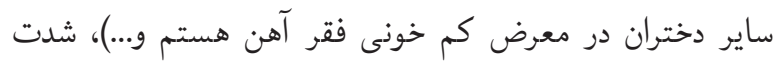

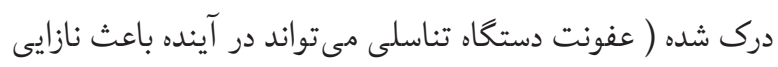

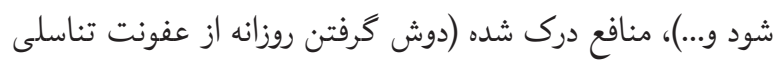

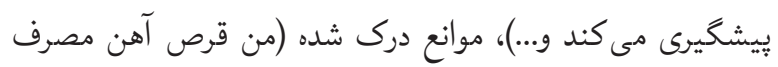

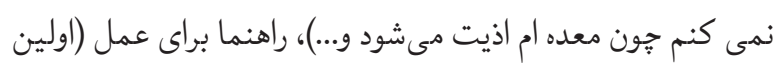

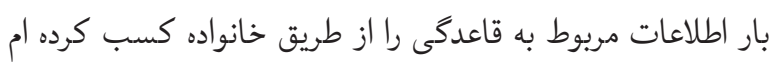
و...)، خودكارآمدى (من مى توانم رفتار بهداشتى دوران بلوغ را بكار

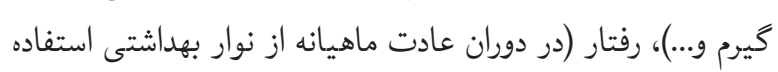

$$
\text { مى كنم و...). }
$$

متغير آكاهى از نمره باسخهاى صحيح و غلط كسب شده فرد

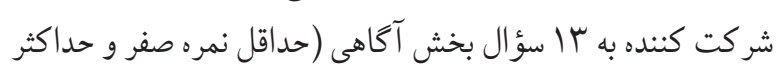

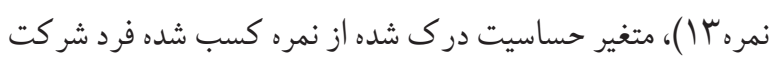
كننده به \ سؤال بخش حساسيت درك شده (حداقل نمره صفر و

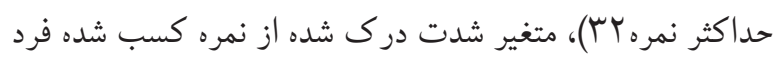

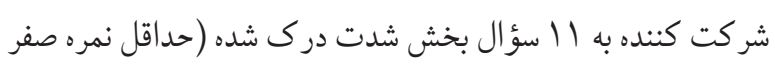
و حد اكثر نمرهF FF)، متغير منافع درك شده از نمره كسب شده فرد

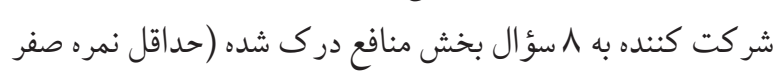

اين اساس تيم تحقيقاتى ما مطالعه اى با هدف تعيين تأثير مداخله آموزشى مبتنى بر مدل اعتقاد بهداشتى بر رفتارهاى بهداشتى دوران

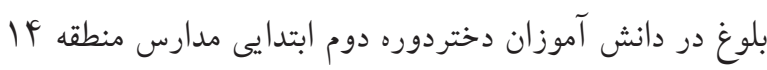
شهر تهران طراحى كرد.

مو اد و روش ها اين يزوهش يك مطالعه مداخله اى نيمه تجبربى با دو گروه

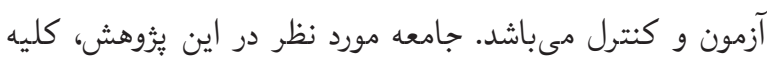

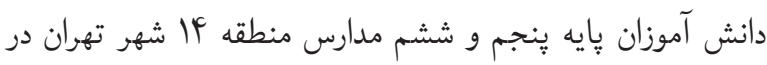
سال

حجم نمونه در اين يُزوهش كه با كمك مشاور آمارى تعيين

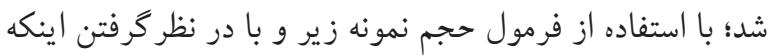

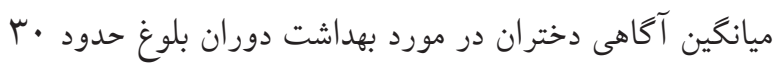

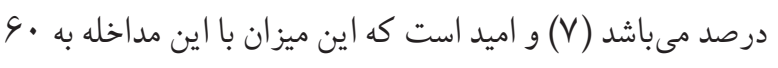

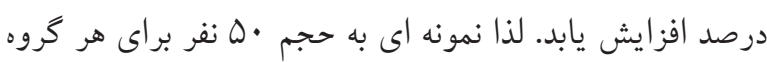

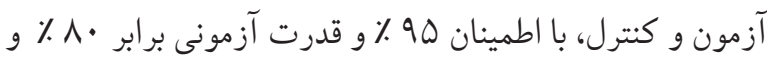

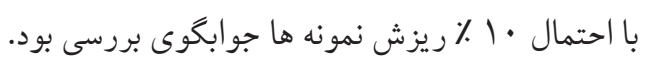

$$
n=\frac{2\left(Z_{1-\frac{\alpha}{2}}+Z_{1-\beta}\right)^{2} P(1-P)}{\left(P_{1}-P_{2}\right)^{2}}
$$

انتخاب نمونه ها به روش نمونه كيرى تصادفى مرحله اي است

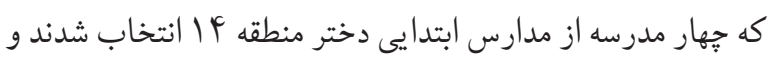
به صورت تصادفى دو مدرسه درگروه كنترل و دو مدرسه دركروه

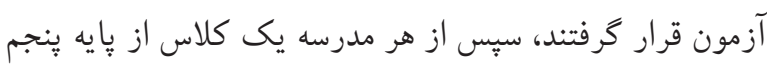
يا ششم به صورت تصادفى انتخاب شدند، معيار ورود به مطالعه هرنه

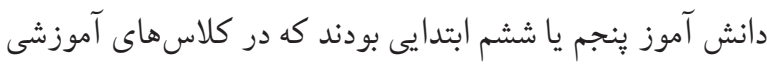

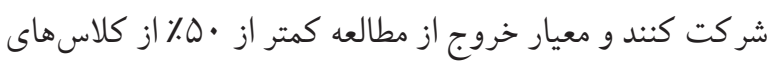
آموزشى را شر كت كرده باشند. با انجام مطالعه كتابخانه اى و بررسى مقالات مرتبط، يرسشنامه برسه

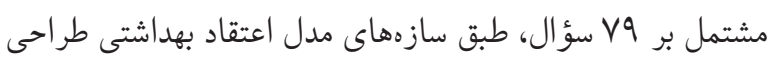

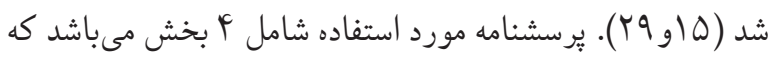


هماهنكى بالاى V/ • مىباشد. لذا توافق بالايى در تأييد روايى صورى و محتواى برسشناهه وجود دارد. جهت بررسى بايايى خارجى يُرسنامه، از روش - test re

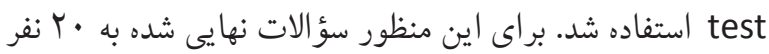

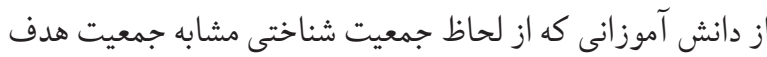

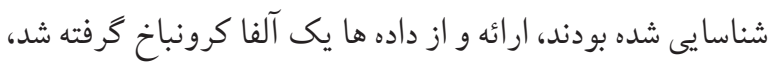

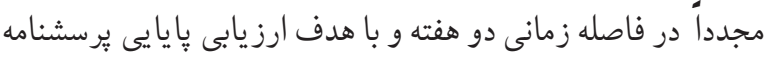

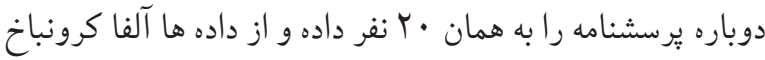

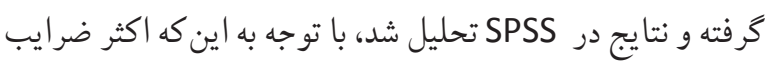

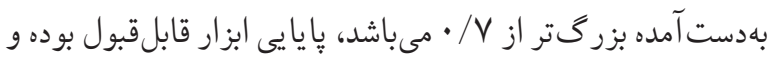
براى بررسى همبستكى و پايايى درونى از آلفاى كرونباخ استفاده

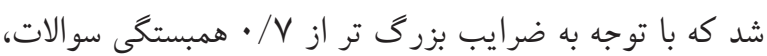
هدف ما را يوشش داد. بدين ترتيب مى توان كفت كه ابزار تحقيق

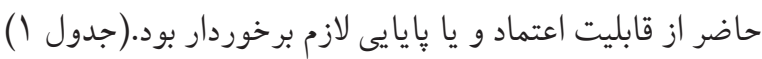

و حداكثر نمرهYr)، متغير موانع درك شده از نمره كسب شده فرد

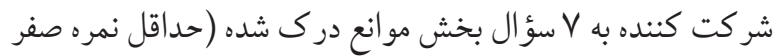
و حداكثر نمرهY)، متغير راهنما براى عمل از نمره كسب شده فرد

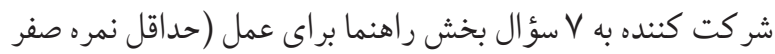

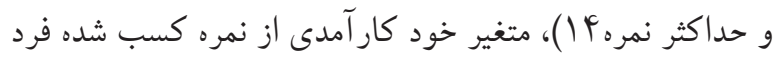

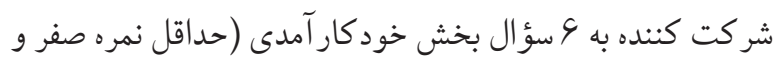

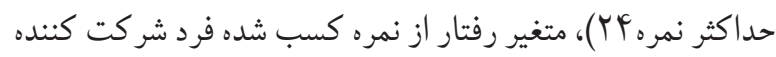
به 19 سؤ ال بخش رفتار (حداقل نمره صفر و حداكثر نمره V9) در

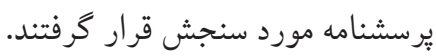
بهمنظور تعيين روايى برسشنامه، ابتدا برسشناهه به • ا انفر از

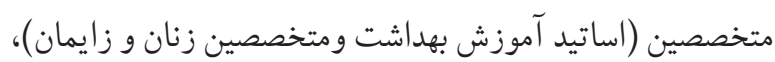

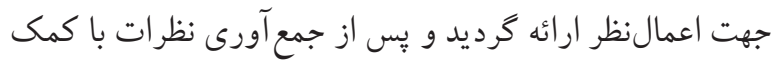

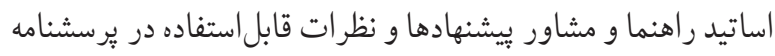
لحاظ شد. نتايج ضر يب هماهنكى (توافق) بررسى شد كه ميزان جدول ا: روايى و يايايى :رسشنامه مورد استفاده جهت جمع آورى داده ها

\begin{tabular}{|c|c|c|c|c|}
\hline روايى CVI & روايى CVR & ميزان آلفاى كرونباخ & تعداد كويه ها & نام متغير \\
\hline$\cdot / \vee 9 \Delta$ &.$/ 9 V r$ & $\cdot / V \Delta$ & ir & آكاهى دانش آموزان \\
\hline$\cdot /$ \^s &.$/ 994$ & $\cdot / \Lambda \Phi^{\mu}$ & $\wedge$ & حساسيت درك شده \\
\hline.$/ 114$ &.$/ 910$ & $\cdot /$ VOr & 11 & شدت درى شده \\
\hline - /VOr &.$/ 9 \vee 0$ & $\cdot / \mathrm{A} \wedge$ & $\wedge$ & منافع درك شده \\
\hline 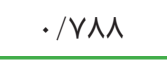 & $\cdot / 1190$ & $\cdot / 111$ & $\checkmark$ & موانع درك شده \\
\hline$\cdot / 19 q$ &.$/ 90 r$ & $\cdot / \mathrm{A} \cdot \mathrm{F}$ & $\checkmark$ & راهنما براى عمل \\
\hline$\cdot / \wedge \vee \Delta$ & $\cdot / 199$ & - /AFr & 4 & خود كار آمدى \\
\hline . MGT &.$/ 994$ & .190 & 19 & رفتار بهداشتى \\
\hline . $/$ Vra &.$/ 9 T V$ & $\cdot / \mathrm{r} \wedge$ & $\vee 9$ & كل ״رسشنامه \\
\hline
\end{tabular}

جهار مدرسه به صورت تصادفى از مدارس ابتدايى دختر انه انتخاب

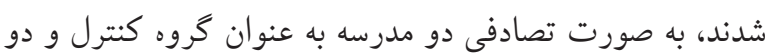

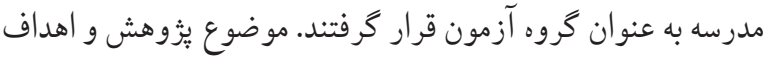
اجراى طرح در جلسه شوراى مدرسه و جلسه انجمن اولياء مربيان مدارس منتخب بيان و كار كنان مدرسه و انجمن اولياء در جريان شيوه اجراى اين طرح قرار گرفتند. يرسشنامه ها توسط دو گروه آزمون و كنترل قبل از انجام مداخله
دانش آموزان دوره دوم ابتدايى كه شرايط ورود به مطالعه را

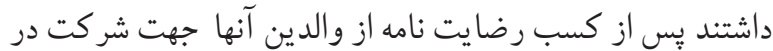

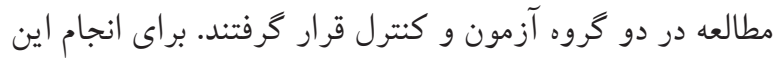

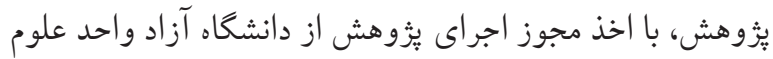

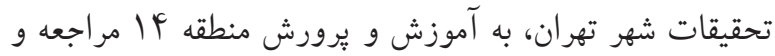

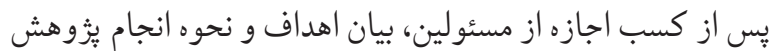
نمونه ها انتخاب شد.با روش نمونه گيرى تصادفى مرحله ایى ، تعداد 
درك شده دانش آموزان در مورد رعايت بهداشت دوران بلوغ بود كه

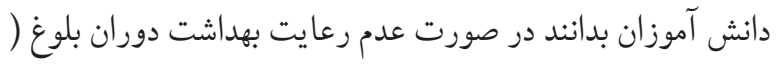

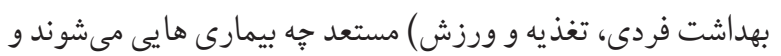
جه عوارضى عدم رعايت بهداشت دوران بلوغ براى آنها دارد. مداخله

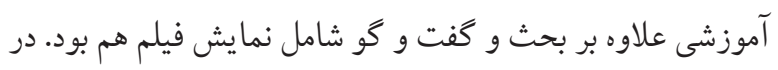

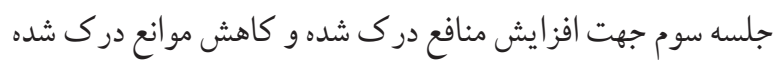

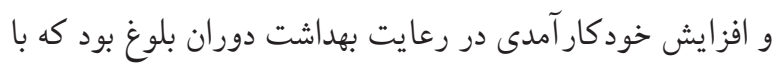

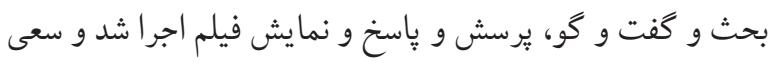

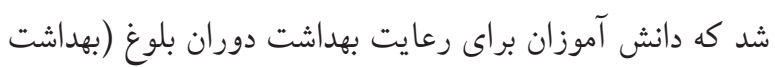
فردى، تغذيه و ورزش) تشويق و ترغيب شوند.
تكميل و داده ها جمع آورى شد. بعد از انجام ييش آزمون، براساس

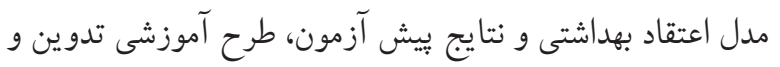

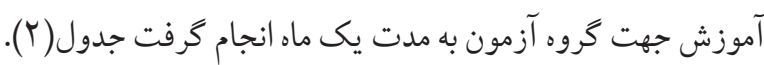

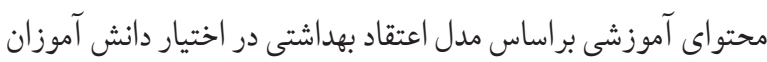

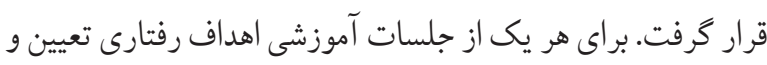

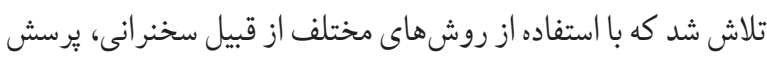
و ياسخ، بحث گروهى، نمايش فيلم به اهداف تعيين شده نائل گرديم.

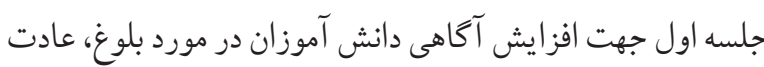

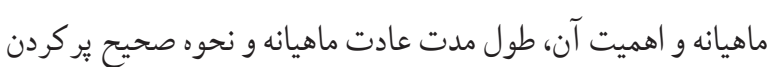
يُرسشنامه بود. جلسه دوم جهت افزايش حساسيت درك شده و شدت مدات

جدول ץ. طرح درس جهت انجام مداخله بر اساس سازههاى مدل اعتقاد بهداشتى

\begin{tabular}{|c|c|c|c|c|}
\hline معيار سنجش & روش تدريس & اهداف رفتارى & هدف كلى & متغير ها \\
\hline آتياز كسب شده بخش برسشامه & 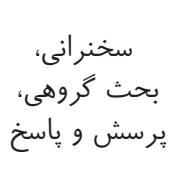 & 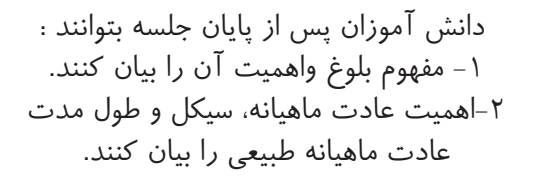 & 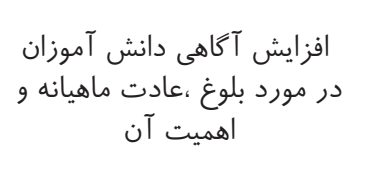 & آ كاهى \\
\hline امتياز كسب شده درى شدش شه & 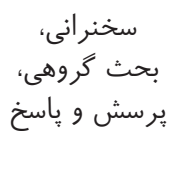 & 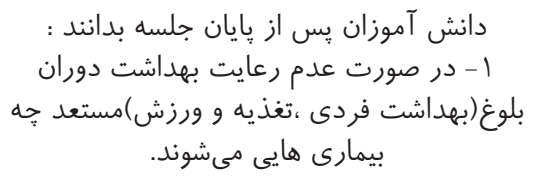 & 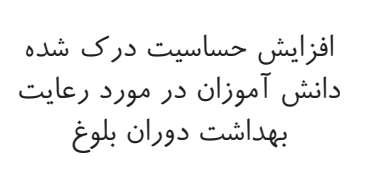 & حساسيت درى \\
\hline بخش شدت درك شب شده شده & 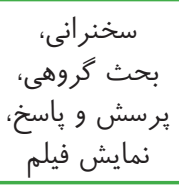 & 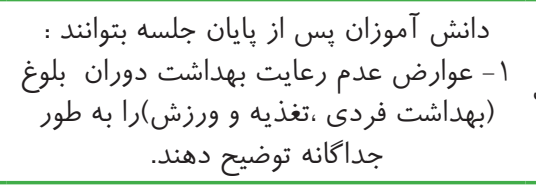 & 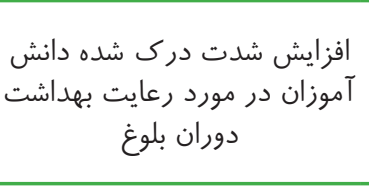 & شدت درى \\
\hline بخش منافع درك شب شده & 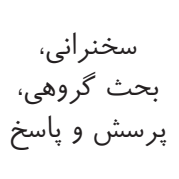 & 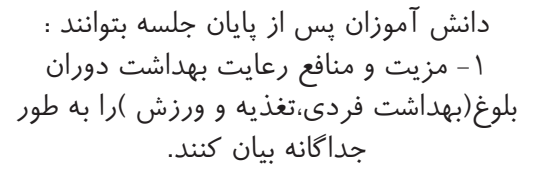 & ه مجزاشت منافع درك شدران بلوغ نسبت بهايت & منافع درى شده \\
\hline بخش موانع درك شد شده & 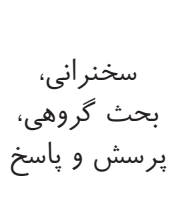 & 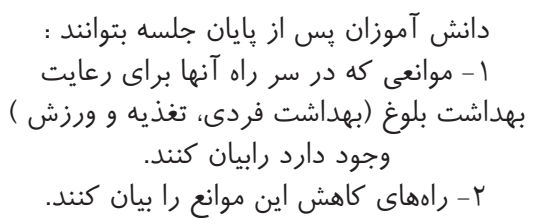 & 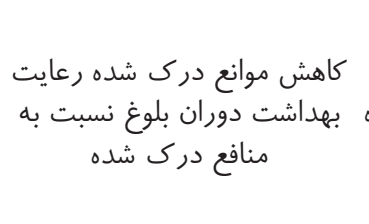 & موانع درك شده \\
\hline
\end{tabular}

و موانع درك شده در دو گروه بررسى شد. داده ها توسط نرم افزار TF.SPSS Anova

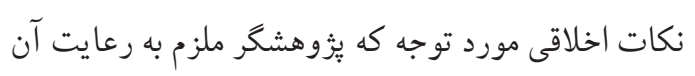


بود شامل: ثبت مطالعه در ايران داك، دريافت كد اخلاق از دانشعاه بافتنه هـا

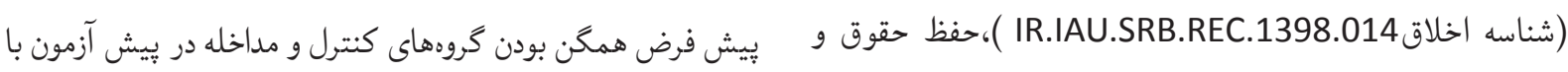

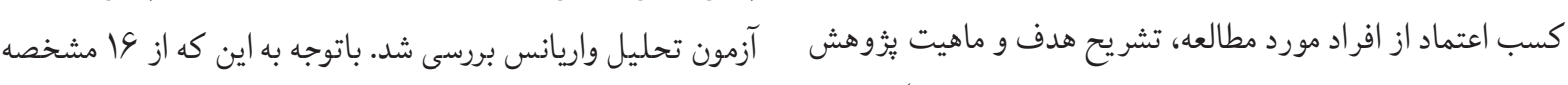

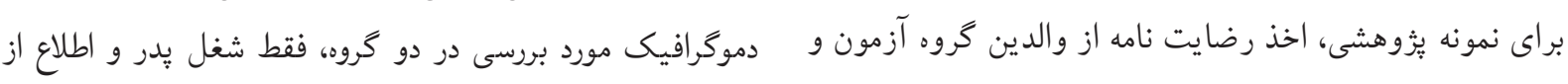

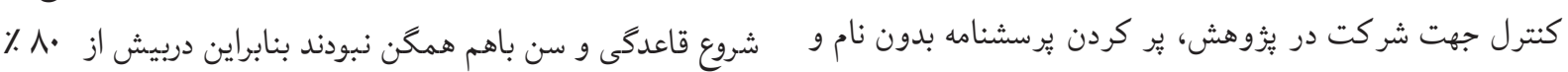

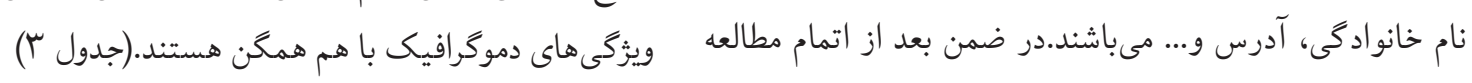

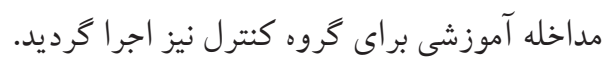
جدول سا: ويثَىهاى دموَّرافيك افراد مورد مطالعه در گَروه آزمون و كنترل

\begin{tabular}{|c|c|c|c|c|}
\hline \multirow{2}{*}{ نتيجه آزمون آمارى كاى دو } & \multirow{2}{*}{ فراوانى(درصد) مداخله } & \multirow{2}{*}{ فراوانى(درصد) } & \multirow{2}{*}{\multicolumn{2}{|c|}{ متغير }} \\
\hline & & & & \\
\hline \multirow{6}{*}{$\begin{array}{c}\mathrm{X}^{r}=\cdot / r \cdot V \\
\mathrm{df}=r \\
\mathrm{P}=\cdot / \Delta V q\end{array}$} & $(r) 1$ & $(r) 1$ & 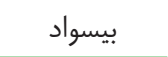 & \multirow{6}{*}{ تحصيلات مادر } \\
\hline & $(Y) 1$ & $(\mathcal{F}) r$ & ابتدايى & \\
\hline & $(I Y) S$ & $(1 \cdot) 0$ & راهنمايى & \\
\hline & 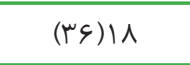 & $(F F) r r$ & دبير ستان & \\
\hline & $(F \wedge) Y F$ & $(r \cdot) r$. & 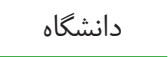 & \\
\hline & $\Delta$. & $\Delta$ & جمع & \\
\hline \multirow{5}{*}{$\begin{array}{c}\mathrm{X}^{r}=\cdot / \Delta r \xi \\
\mathrm{df}=r \\
\mathrm{P}=\cdot / \uparrow \varsigma \Lambda\end{array}$} & $(\mid Y) \varphi$ & $(\mid F) V$ & 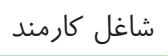 & \multirow{5}{*}{ شغل مادر } \\
\hline & $(\boldsymbol{l}) r$ & $(\mid Y) S$ & غير كارمند & \\
\hline & $(\varsigma) \mu$ & $(\boldsymbol{f}) r$ & بازنشسته & \\
\hline & $($ V^) rq & $(V \cdot) \mu^{m}$ & خانه دار & \\
\hline & $\Delta$ & $\Delta \cdot$ & جمع & \\
\hline \multirow{5}{*}{$\begin{array}{c}\mathrm{X}^{r}=11 / \mathrm{rq} \\
\mathrm{df}=r \\
\mathrm{P}=\cdot / \cdots 1\end{array}$} & $(r \wedge) \backslash F$ & $(\Delta \wedge) r q$ & 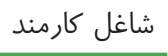 & \multirow{5}{*}{ شغل بدر } \\
\hline & $(\Delta \wedge) r q$ & $(\boldsymbol{f} \cdot) r \cdot$ & غير كارمند & \\
\hline & $(\mid r) \varphi$ & $(r) 1$ & بازنشسته & \\
\hline & $(r) 1$ & . & بيكار & \\
\hline & $\Delta \cdot$ & $\Delta$ & جمع & \\
\hline \multirow{6}{*}{$\begin{array}{c}\mathrm{X}^{r}=r / \mu \wedge \Lambda \\
\mathrm{df}=r \\
\mathrm{P}=\cdot / \cdot \wedge \Delta\end{array}$} & . & . & 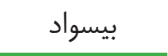 & \multirow{6}{*}{ تحصيلات پيدر } \\
\hline & $(\varsigma) \mu$ & . & 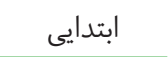 & \\
\hline & $(1 \cdot) \Delta$ & $(\Lambda)^{q}$ & راهنمايى & \\
\hline & (ז\&) r & $\left(\mu^{\mu}\right.$ & دبير ستان & \\
\hline & $($ ( & $(\Delta \varsigma) \nvdash \wedge$ & 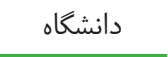 & \\
\hline & $\Delta \cdot$ & $\Delta \cdot$ & جمع & \\
\hline \multirow{2}{*}{$\begin{array}{c}\mathrm{X}^{r}=\mathrm{V} / \wedge 9 \\
\mathrm{df}=1 \\
\mathrm{P}=\cdot / \cdots \mathrm{V}\end{array}$} & $(\xi \Lambda))^{\mu}$ & $(F F) r r$ & بله & \multirow{2}{*}{ قاعدلاع از شروعى } \\
\hline & (rT)\S & $(\Delta \varphi) r \wedge$ & خير & \\
\hline
\end{tabular}


ادامه جدول سّ: ويز گىهاى دمو گرافيك افراد مورد مطالعه در گروه آزمون و كنترل

\begin{tabular}{|c|c|c|c|}
\hline \multirow{2}{*}{ نتيجه آزمون تى مستقل } & كروه آزمون & كروه كنترل & \multirow{2}{*}{ ت تغير } \\
\hline & ميانگين و انحراف معيار & ميانگين و انحراف معيار & \\
\hline \multirow{6}{*}{$\begin{array}{c}\mathrm{t}=r / \backslash \Delta r \\
\mathrm{df}=q \Lambda \\
\mathrm{P}=\cdot / \cdot r r\end{array}$} & $|1 / 4 \pm \cdot| q \mid$ & $11 / 1 \pm \cdot / 09$ & \multirow{2}{*}{ سن (سال) } \\
\hline & فراوانى(درصد) & فر اوانى (درصد) & \\
\hline & $(\mathfrak{f}) r$ & $(1 \cdot) \Delta$ & 1. \\
\hline & $(\Delta \cdot) r \Delta$ & $(G Y) T_{1}$ & 11 \\
\hline & $(F F) Y T$ & $(Y \wedge) \mid F$ & ir \\
\hline & $(r) 1$ & $(\cdot) \cdot$ & Ir \\
\hline \multirow{6}{*}{$\begin{array}{c}t=1 / \cdot \vee \\
d f=9 \wedge \\
P=\cdot / r \wedge \vee\end{array}$} & $f / 1 \pm 1 / .9$ & $r / 9 \pm \cdot / 90$ & \multirow{2}{*}{ تعداد اعضاى خانواده } \\
\hline & فراوانى(درصد) & فراوانى (درصد) & \\
\hline & $(Y F) \backslash Y$ & $(r \wedge) \backslash F$ & $r$ \\
\hline & (fs)rr & $(\Delta S) Y \wedge$ & f \\
\hline & $(Y F) \mid Y$ & $(\boldsymbol{F}) \boldsymbol{r}$ & $\Delta$ \\
\hline & $(\boldsymbol{f}) \mu$ & $(\mid r) s$ & بيشتر \\
\hline \multirow{6}{*}{$\begin{array}{c}\mathrm{t}=-\cdot / Y F F \\
\mathrm{df}=9 \wedge \\
\mathrm{P}=\cdot / \Lambda \cdot \vee\end{array}$} & 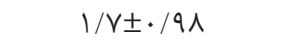 & $1 / f \pm 1 / f$ & \multirow{2}{*}{ 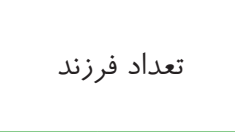 } \\
\hline & فراوانى(درصد) & فراوانى (درصد) & \\
\hline & $(\mathbb{F} \varphi) r \mu$ & $(\Delta \cdot) r \Delta$ & 1 \\
\hline & $(\boldsymbol{r} \cdot) r \cdot$ & $(\mu F) \backslash V$ & r \\
\hline & $(\mid r) s$ & $(\varsigma) \mu$ & r \\
\hline & $(r) 1$ & $(1 \cdot) 0$ & بيشتر \\
\hline \multirow{6}{*}{$\begin{array}{c}\mathrm{t}=1 / \cdot v \\
\mathrm{df}=9 \wedge \\
\mathrm{P}=\cdot / r \wedge \vee\end{array}$} & $p / l \pm 1 / . q$ & $r / 9 \pm \cdot / 90$ & \multirow{2}{*}{ تعداد خواهران } \\
\hline & فراوانى(درصد) & فراوانى(درصد) & \\
\hline & سش(૬૬) & $(V F) T^{\mu} V$ & · \\
\hline & r & $(19) \wedge$ & 1 \\
\hline & $(Y) 1$ & $(\boldsymbol{f}) r$ & r \\
\hline & $(\varsigma) \mu$ & (द) & 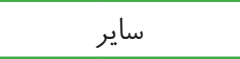 \\
\hline \multirow{5}{*}{$\begin{array}{c}\mathrm{t}=-1 / 1 \wedge \mathrm{f} \\
\mathrm{df}=9 \wedge \\
\mathrm{P}=\cdot / r \Delta 1\end{array}$} & $r / s \pm 1 / r$ & $r / \cdot r \pm 1 / v$ & \multirow{2}{*}{ در آمد خانواده } \\
\hline & فراوانى(درصد) & فراوانى (درصد) & \\
\hline & $(\Delta F) Y V$ & $(\Delta \cdot) r \Delta$ & زير r مام \\
\hline & $\left(\Psi^{\prime}\right) \backslash S$ & $(\mu F) \mid V$ & $\rho r-r$ \\
\hline & $(\mid F) V$ & $(19) \wedge$ & بالاتر از أم \\
\hline
\end{tabular}

جداول فوق نشان مىدهد كه بين دو گروه كنترل و مداخله قاعدگى، ترس از قاعدگى و زندگى با خانو اده از نظر آمارى تفاوت

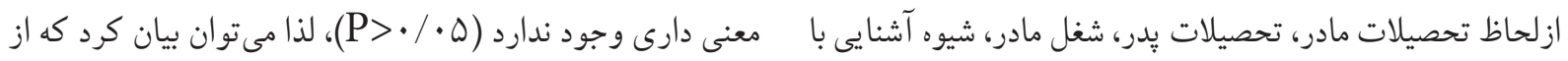


نظر و يز گىهاى تحصيلات يدر و مادر و شغل مادر، شيوه آشنايى با دوره قاعدگى و سن قاعدگى دو گروه در وضعيت اوليه يكسانى

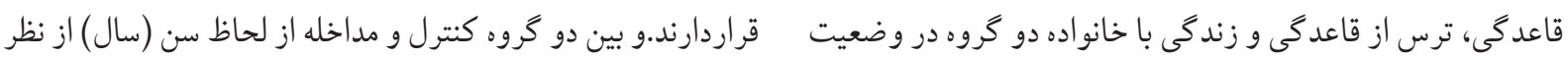

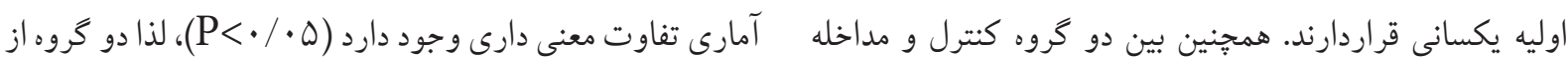

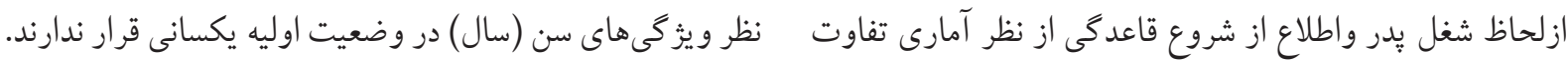

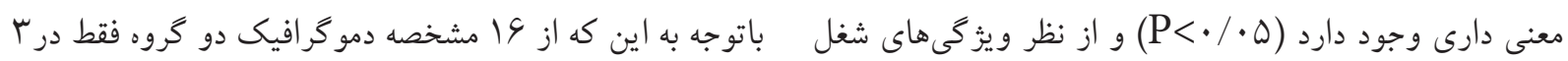

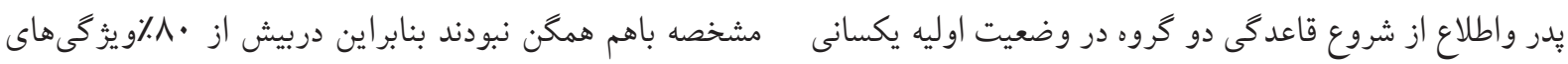

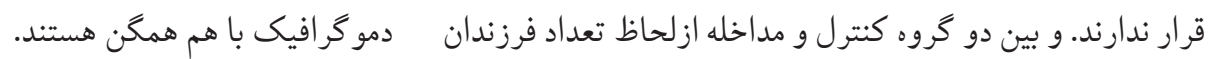

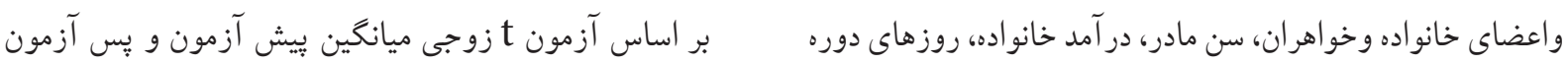

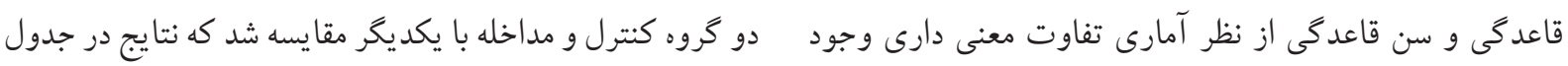

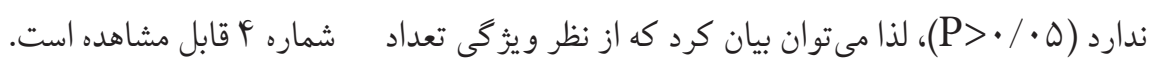

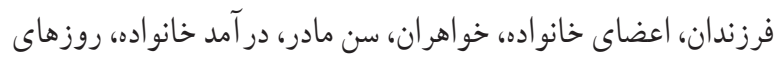

جدول أ: مقايسه سازه آكًاهى و سازهاى مدل اعتقاديبهداشتى در تأثير مداخله آموزشى مبتنى بر مدل بر رفتار دوران بلوغ در دو كروه قبل و بعد از مداخله

\begin{tabular}{|c|c|c|c|c|}
\hline p-value & اختلاف ميانكين و انحراف معيار بيش و وِّ & p-value & 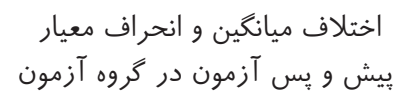 & هدف \\
\hline $\mathrm{P}=\cdot / \mu_{1}$ & $\cdot / \cdot \pm \varepsilon / \Lambda F$ & $\mathrm{P}=\cdot / \cdot r$ & $1 / 9 \pm \cdot / \mu$ & آكاهى \\
\hline $\mathrm{P}=\cdot / 1 \mu \mu$ & $\cdot / 1 \pm \Delta / r$ & $\mathrm{P}=\cdot / \cdot \cdot 1$ & $r / l r \pm \cdot / r$ & حساسيت درك شده \\
\hline $\mathrm{P}=. / .99$ & $r / \Lambda \pm r / r \mu$ & $\mathrm{P}=\cdot / \cdot \cdot 1$ & $4 / 1 \wedge \pm \cdot / \cdot 1$ & شدت درك شده \\
\hline $\mathrm{P}=\cdot / r r$ & $\cdot / I \pm r / / V$ & $\mathrm{P}=\cdot / \Delta s \mathrm{~V}$ & $\cdot / r s \pm r / 1$ & منافع درك شده \\
\hline $\mathrm{P}=\cdot / \cdot \mathrm{VI}$ & $-1 / \cdot \pm V / 1$ & $\mathrm{P}=\cdot / \cdot \cdot 1$ & $-\varsigma / \cdot r \pm r / \mu$ & موانع درك شده \\
\hline $\mathrm{P}=\cdot / 19 \mu$ & $1 / \cdot \pm \cdot / 4$ & $\mathrm{P}=\cdot / \cdot \cdot 1$ & $r / q \pm r / q$ & راهنما براى عمل \\
\hline $\mathrm{P}=$-/ArS & $\cdot / \cdot \pm r / V$ & $\mathrm{P}=\cdot / \mathrm{VV}{ }^{\mathrm{F}}$ & $\cdot / \mu \pm \cdot / r$ & خوكار آمدى \\
\hline $\mathrm{P}=\cdot / / \mu q$ & $r / I \pm r / r r$ & $\mathrm{P}=\cdot / \cdot r /$ & $\Delta / \tilde{T} \pm 1 / 1$ & عملكرد \\
\hline
\end{tabular}

بهداشتى بر آكاهى دانش آموزان در رفتار بهداشتى در دوران بلوغ

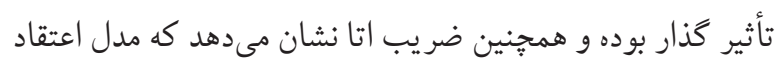

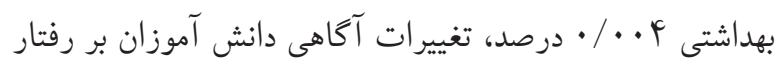
بهداشتى در دوران بلوغ را تبيين مى كند. نتايج آزمون t زوجى نشان داد كه بين نمره ميانخين حساسيت

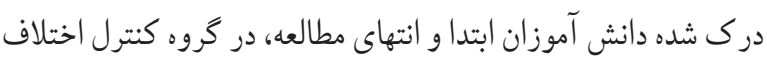

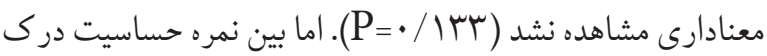
شده دانش آموزان قبل و بعد از مداخله در كروه آزمون اختلاف

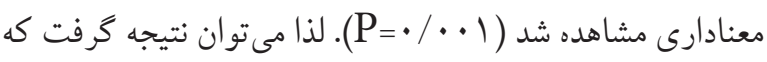

نتايج آزمون t زوجى نشان داد كه بين نمره ميانكين آكاهى

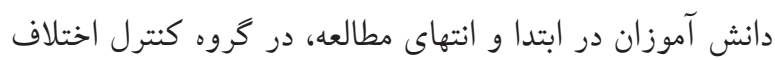

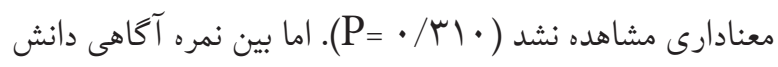

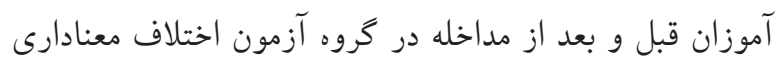

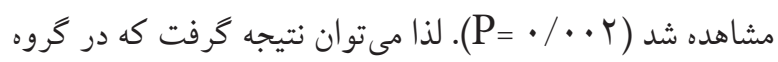

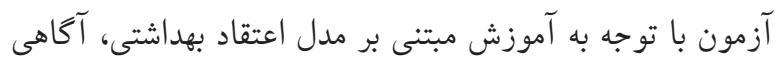

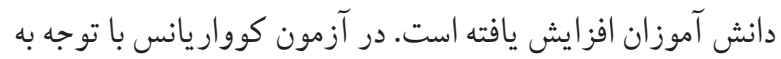

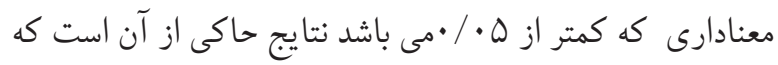
با سطح اطمينان 99 درصد، مداخله آموزشى مبتنى بر مدل اعتقاد 
ازه • / مى مباشد، نتايج حاكى از آن است كه با سطح اطمينان

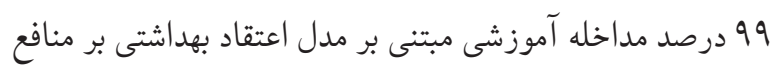
درك شده دانش آموزان بر رفتار بهداشتى در دوران بلوغ تمدئ تأثير كذار نبوده است.

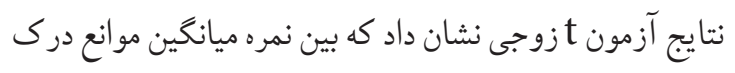

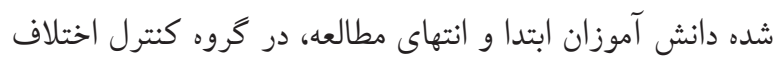

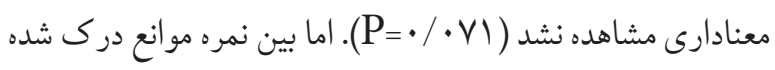

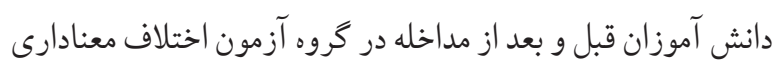

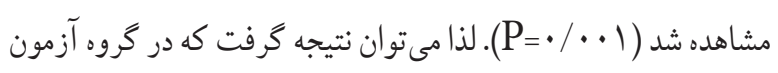

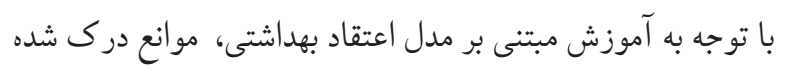

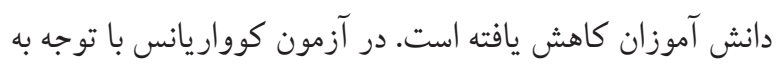

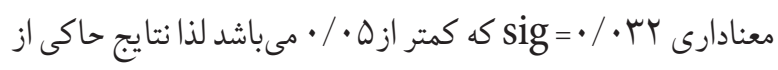

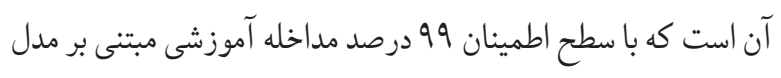

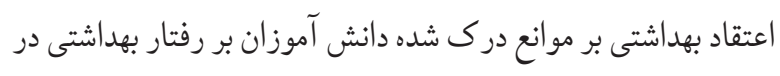

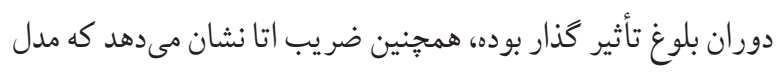

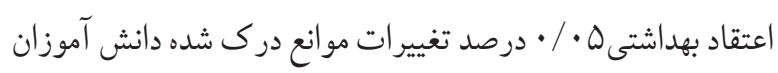
در رفتار بهداشتى دوران بلوغ را تبيين مى كند.

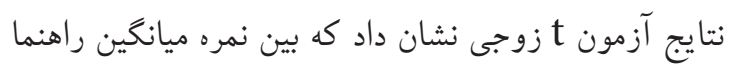

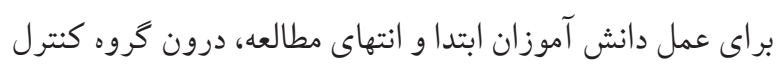

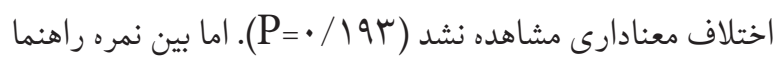

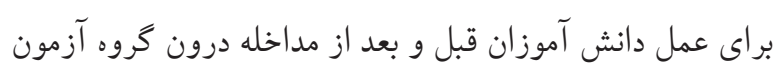

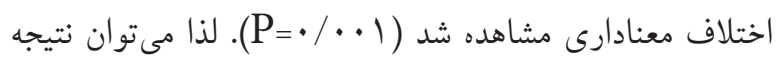

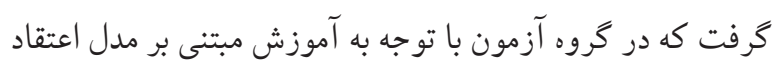

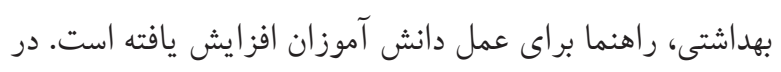

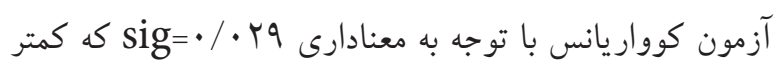
از ه • • م مى باشد نتايج حاكى از آن است كه با سطح اطمينان 99

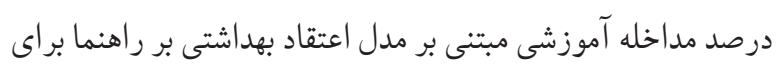

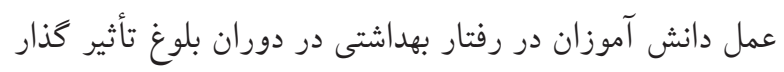

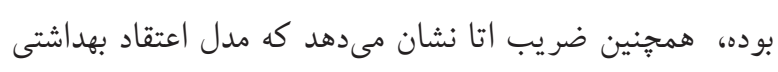
19 • • • درصد تغييرات راهنما براى عمل دانش آموزان بر رفتار بهداشتى در دوران بلوغ را تبيين مى كند.
در كروه آزمون با توجه به آموزش مبتنى بر مدل اعتقاد بهداشتى، آنقا

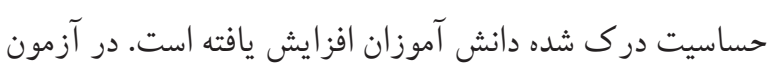

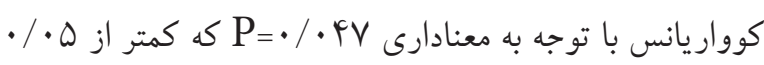

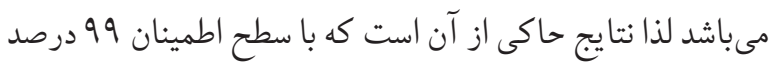

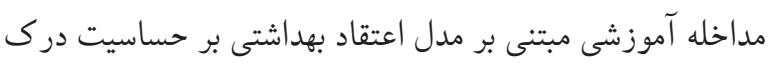

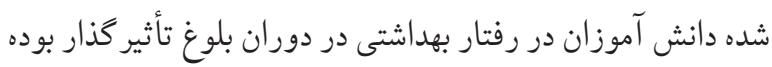

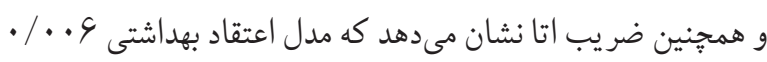

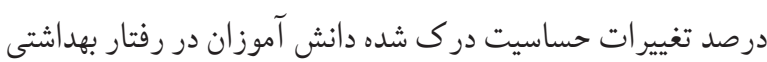
در دوران بلوغ را تبيين مى كند.

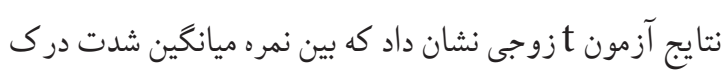

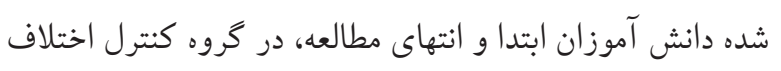

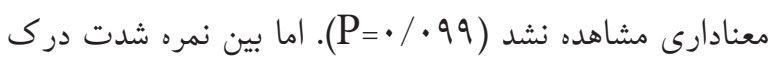

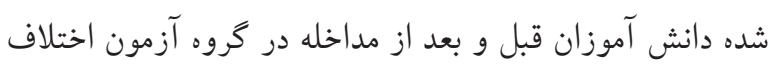

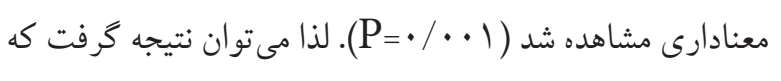

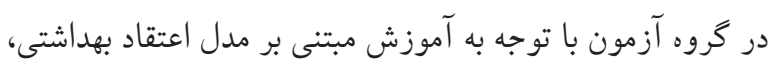

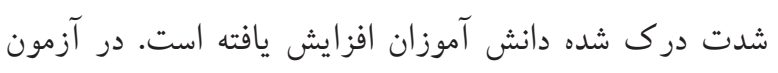

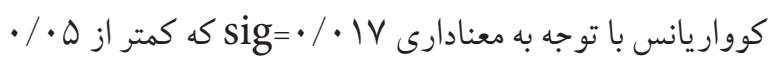
مى باشد لذا نتايج حاكى از آن است كه با سطح اطمينان 99 درصد

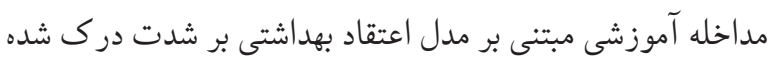

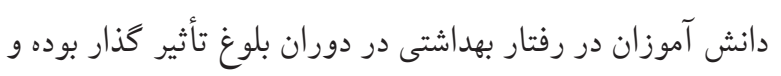

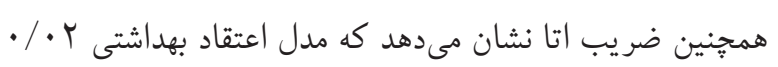

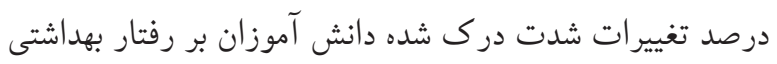
در دوران بلوغ را تبيين مى كند.

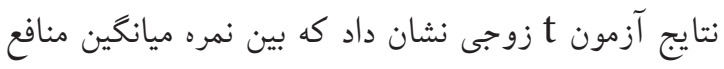

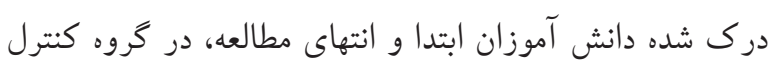

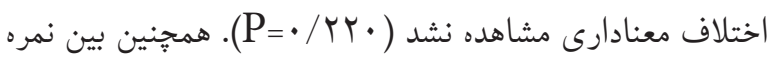

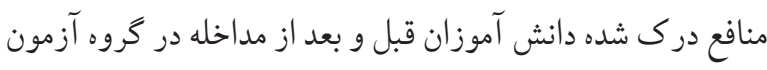

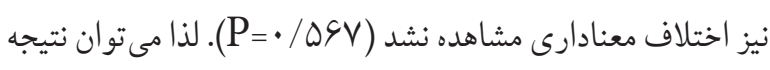

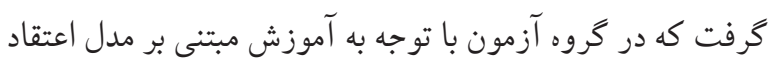

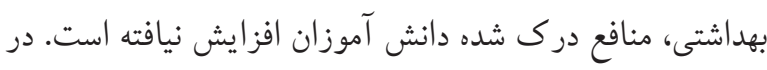

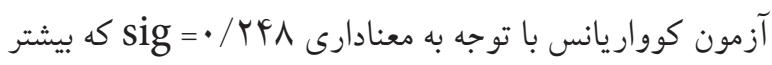


مبتنى بر مدل اعتقاد بهداشتى بر رفتار بهداشتى دانش آموزان در

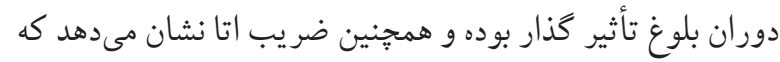

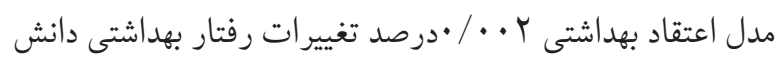
آموزان در دوران بلوغ را تبيين مى كند. جهت بررسى ميزان تأثير و شيوه تأثير كذارى مداخله از آزمون آنكوا (تحليل كوواريانس يك طرفه) براى مقايسه اثر مداخله

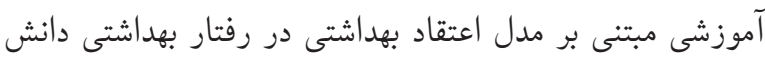

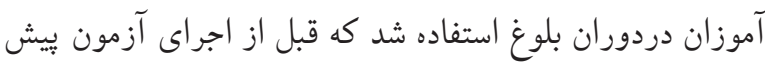

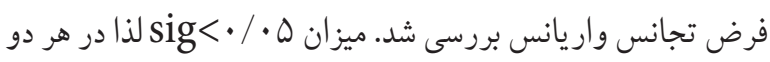

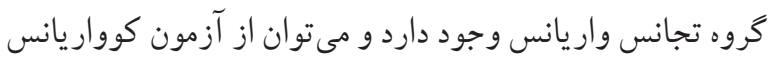
براى مقايسه گروه ها استفاده كرد. همجنين در تمامى گروه ها اثرات

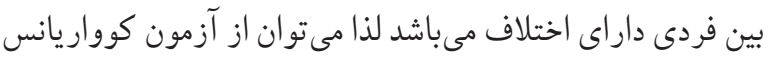

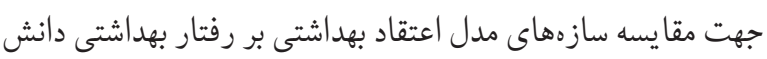
آموزان دردوران بلوغ بر متغيرهاى تحقيق استفاده كرد.

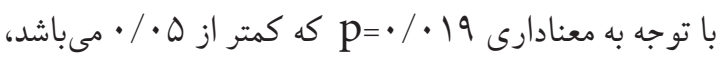
نتايج حاكى از آن است كه مداخله آموزشى مبتنى بر مدل اعتقاد

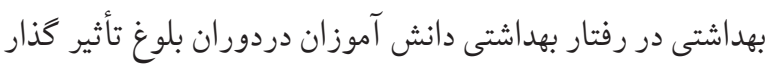
بوده لذا مىتوان بيان كرد كه با سطح اطمينان 99 درصد مداخله

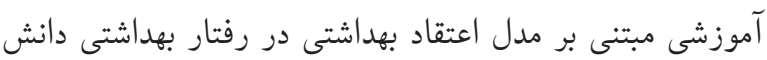
آموزان تأثير معنادارى دارد (جدوله).
نتايج آزمون t زوجى نشان داد كه بين نمره ميانكين خودكار آمدى

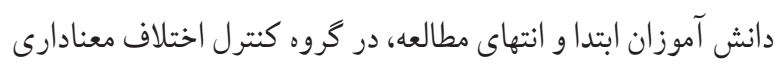

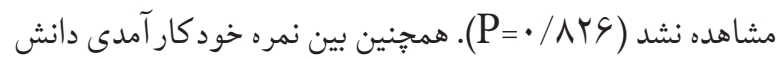
آموزان قبل و بعد از مداخله در گروه آزمون اختلاف معنادارى مشاهده

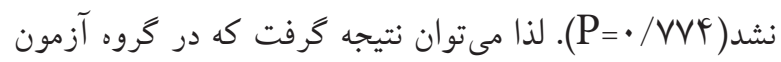

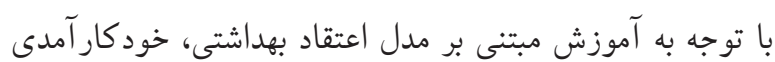

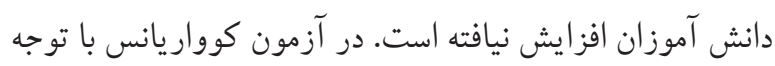

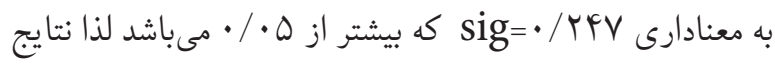

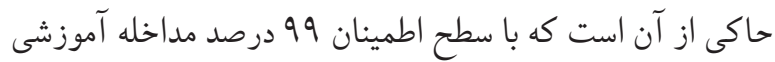

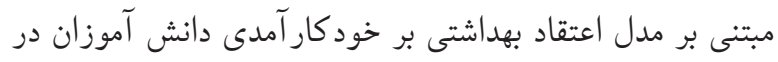

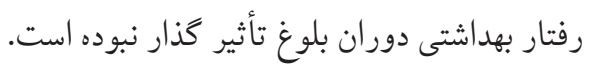
نتايج آزمون t زوجى نشان داد كه بين نمره ميانخين رفتار

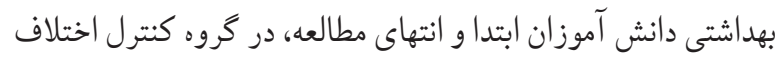

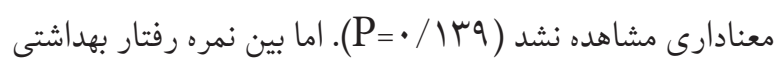

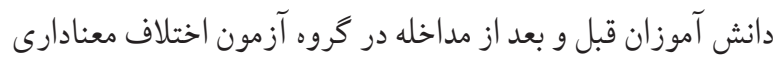

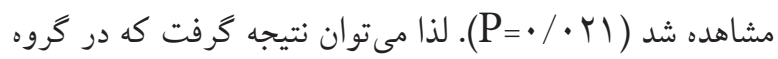

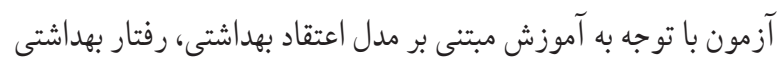

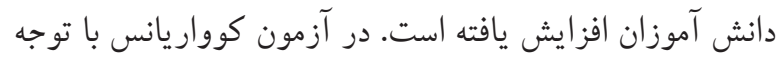

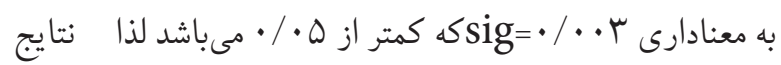
حاكى از آن است كه با سطح اطمينان 99 درصد مداخله آموزشى له

جدول ه: تأثير آموزش بر رفتار بهداشتى دانش آموزان با توجه به آزمون كوواريانس مجانس

\begin{tabular}{|c|c|c|c|c|c|c|c|c|}
\hline توان آزمون & ضريب اتا & Sig & $\mathbf{F}$ & مجذانگين & Df & مجذورات & & \\
\hline \multirow[t]{2}{*}{.$/ 191$} & $\cdot / \cdot 1$ & $\cdot 1 \cdot 19$ & $1 / \cdots r$ & $V \cdot s / \Lambda$ & 1 & $V \cdot s / \Lambda$ & مقدار ثابت & \multirow{2}{*}{ اثر آموزش بر رفتار } \\
\hline & & & & $V \Delta V / q$ & $9 V$ & $V V^{\mu} \Delta / s / \Lambda$ & خطا & \\
\hline
\end{tabular}

\section{براى مقايسه ميزان تأثير عوامل دمو كرافيك دانش آموزان بحث}

مطالعه حاضر با هدف تعيين تأثير مداخله آموزشى مبتنى بر مدل

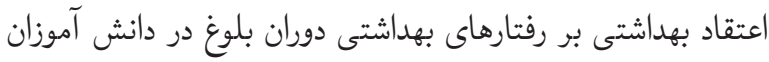

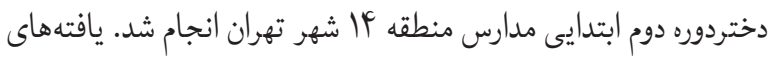

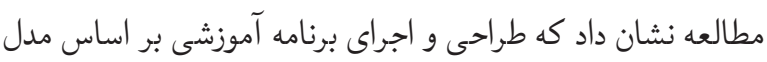

بر رفتار بهداشتى دانش آموزان دردوران بلوغ از آزمون تحليل

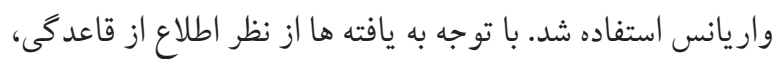

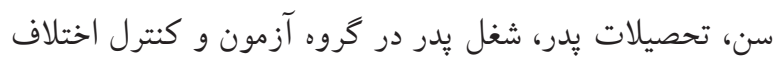

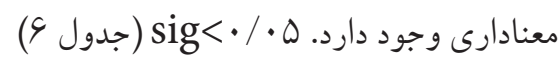


جدول 9: تأثير عوامل دمو كرافيك دانش آموزان بر رفتار بهداشتى دانش آموزان

\begin{tabular}{|c|c|c|c|c|c|c|}
\hline Sig & $\mathbf{F}$ & ميانگين مربعات & df & مجموع مربعات & & \\
\hline \multirow[t]{3}{*}{.$/ \cdot \mu q$} & $F / \varepsilon \mu$ & $1 / 99$ & 1 & $1 / 99$ & بين گروه ها & \multirow{3}{*}{ سن } \\
\hline & & $\cdot / \mu G F$ & 91 & $r \Delta / \mathrm{V}$ & درون گروه ها & \\
\hline & & & 99 & $\mu \vee / \mu$ & مجموع & \\
\hline \multirow[t]{3}{*}{$\cdot / \cdot r$} & $1 / \Delta$ & $1 / 97$ & 1 & $1 / 9 F$ & بين گروه ها & \multirow{3}{*}{ اطلاع از قاعدگى } \\
\hline & & . /rrq & $9 \wedge$ & $r I / V$ & درون گروه ها & \\
\hline & & & 99 & $r \mu / S$ & مجموع & \\
\hline \multirow[t]{3}{*}{$\cdot / \cdot 1$} & $|r / 4|$ & $r / \Lambda$ & 1 & $r / \Lambda$ & بين گروه ها & \multirow{3}{*}{ شغل پدر } \\
\hline & & $\cdot /$ rAF & 91 & $r V / s$ & درون گروه ها & \\
\hline & & & 99 & $F r / F$ & مجموع & \\
\hline \multirow[t]{3}{*}{$\cdot / \cdot \mu s$} & $F / \Delta F$ & $r / \Delta S$ & 1 & $r / \Delta S$ & بين گروه ها & \multirow{3}{*}{ تحصيلات يدر } \\
\hline & &.$/ \Delta S \mu$ & 91 & $\Delta \Delta / r$ & درون گروه ها & \\
\hline & & & 99 & $\Delta V / V$ & مجموع & \\
\hline
\end{tabular}

بين نمره حساسيت درك شده دانش آموزان قبل و بعد از مداخله درون كروه آزمون اختلاف معنادارى مشاهده شد. با سطح اطمينان

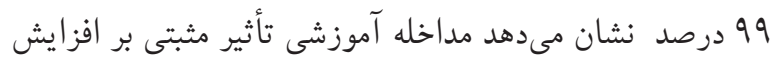

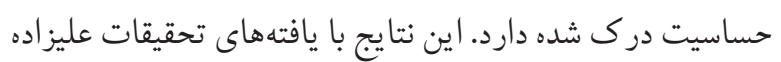

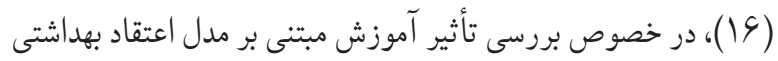

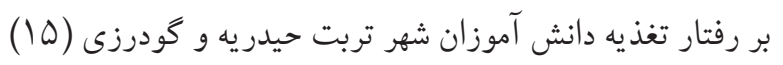

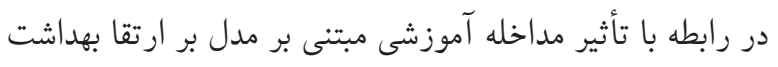
جسمى بلوغ دختران هم راستا مىباشد.

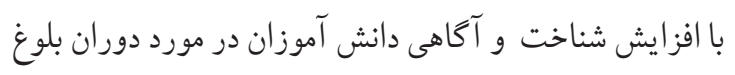

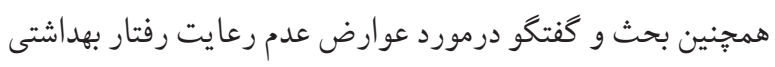

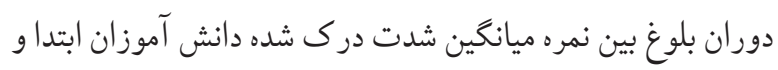
انتهاى مطالعه، درون گروه كنترل اختلاف معنادارى مشاهده نشد. اما بين نمره شدت درك شده دانش آموزان قبل و بعد از مداخله

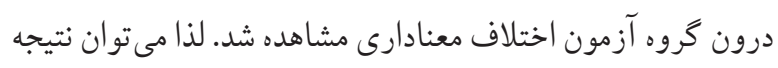

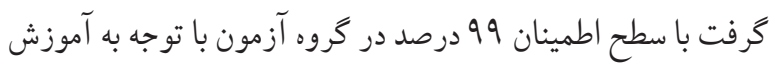
مبتنى بر مدل اعتقاد بهداشتى بر شدت درك شده دانش آموزان

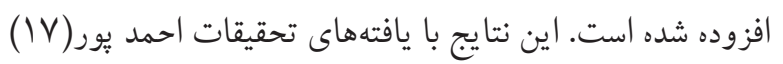

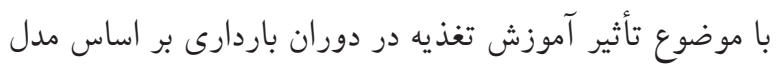

اعتقاد بهداشتى در زمينه رفتارهاى بهداشتى دوران بلوغ مىتواند سطح اين رفتار ها را بهبود دهد.

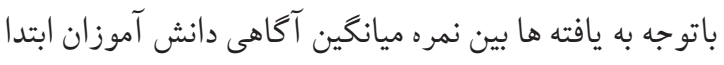

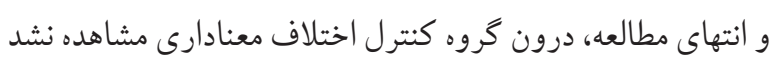
ـ اما بين نمره آكاهى دانش آموزان قبل و بعد از مداخله درون كرون كروه

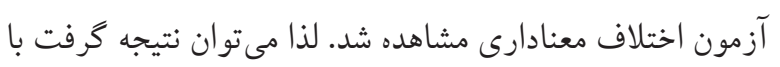

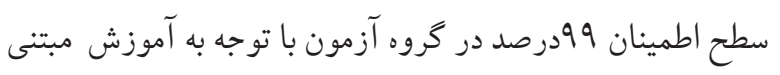
بر مدل اعتقاد بهداشتى، آكاهى دانش آموزان افزايش يافته است. و اين نتايج با يافتهاى تحقيقات عابدى (F) (I)، با موضوع تعيين

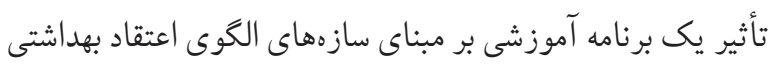

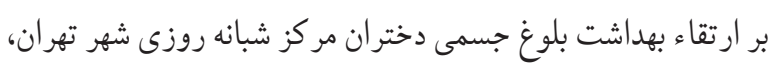

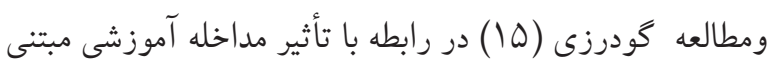

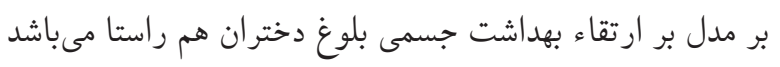

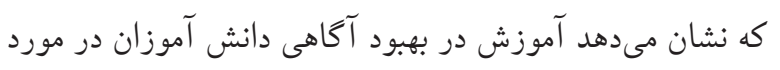
رفتارهاى بهداشتى دوران بلوغ تأثير مثبت داشته است.

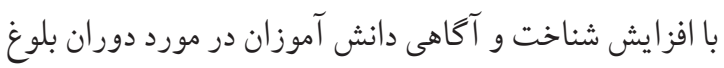
نمره ميانكين حساسيت درك شده دانش آموزان ابتدا و انتهاى

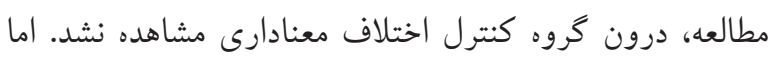


حجب و حيا در برسش در زمينه بلوغ در زمان آموزش و همجنين

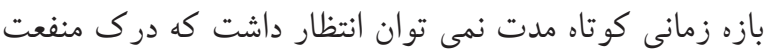

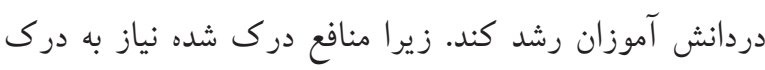

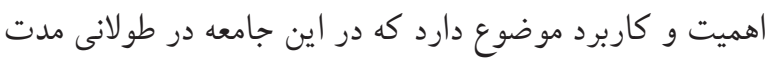

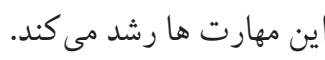

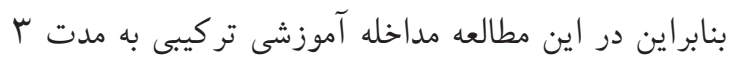
جلسه DF دقيقه اى براى جامعه هدف (دانش آموزان دوره دوم

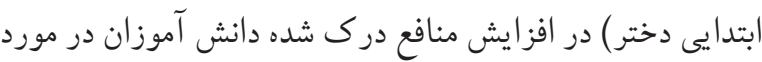

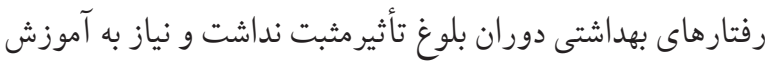
در يك بازه زمانى طولانى تر مى باشد.

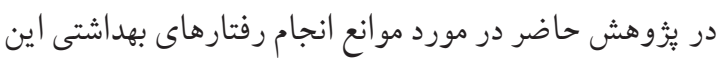

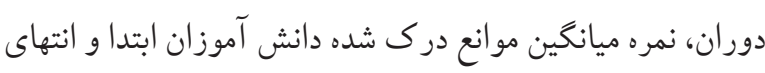
مطالعه، درون گروه كنترل اختلاف معنادارى مشاهده نشد. اما بين

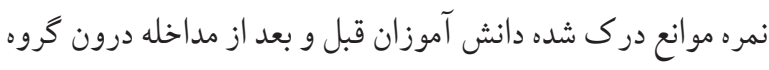

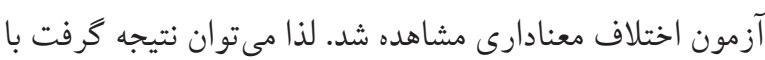

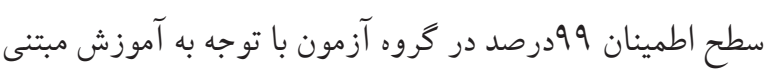

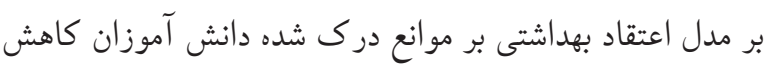

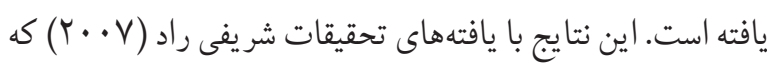

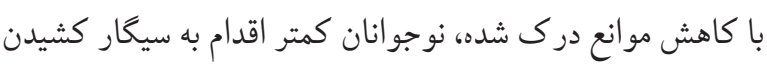

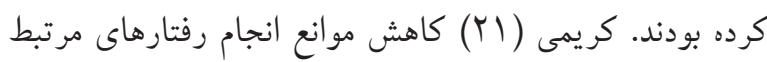

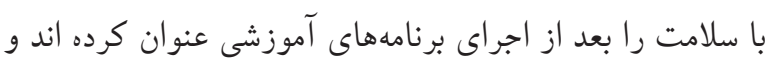

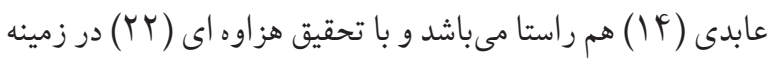

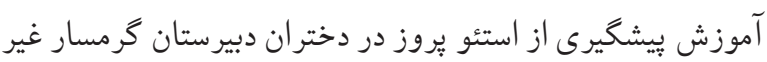

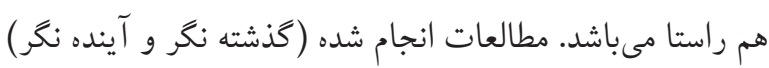

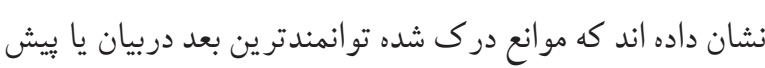
بينى رفتارهاى محافظت كننده سلامتى است (T (T).

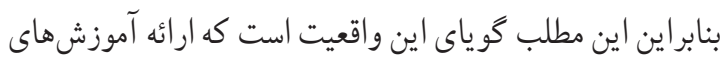

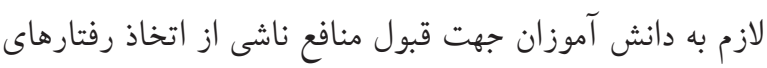
ارتقاء دهنده بهداشت بلوغ و غلبه آنان بر موانع مو جود در زمينه اتخاذ رفتارهاى ارتقاء دهنده بهداشت بلوغ ضرورى است (I I ( ).

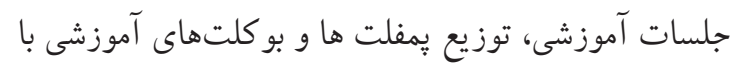

اعتقاد بهداشتى بر آكاهى و نكرش و عملكرد زنان مراجعه كننده

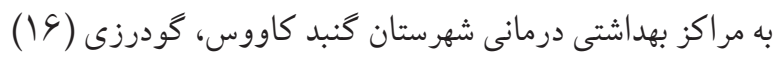
در خصوص تأثير مداخله آموزشى برارتقا رفتارهاى دوران بلوغ دنان

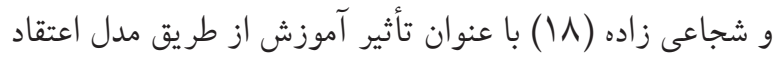

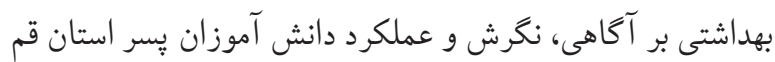
در مورد مصرف صبحانه هم راستا مىباشد.

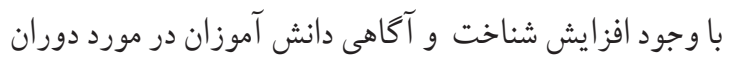
بلوغ همجنين بحث و كفتخو در منفعت كسب شده در مورد رعايت

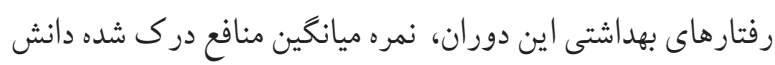

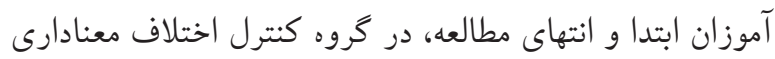
مشاهده نشد. همجنين بين نمره منافع درك شده دانش آموزان

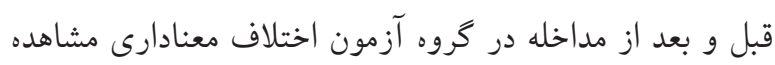

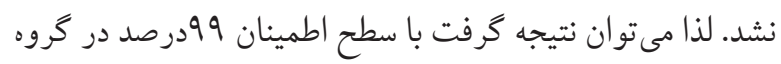

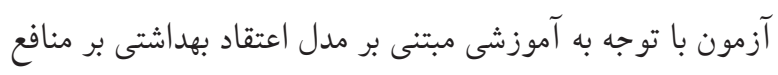

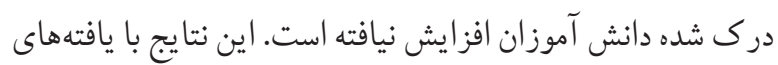
تحقيقات صادقى (19) با موضوع كاربرد مدل اعتقاد بهداشتى در

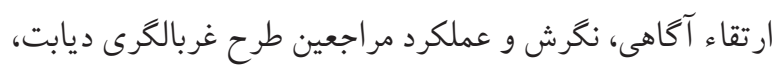

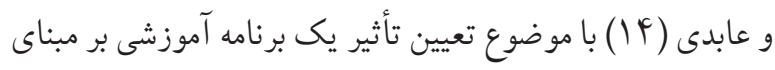

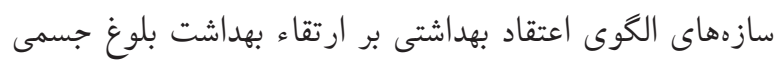

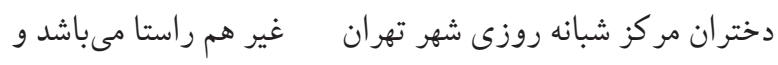

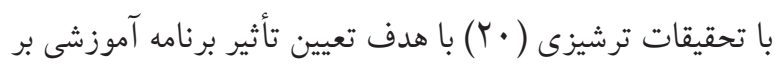

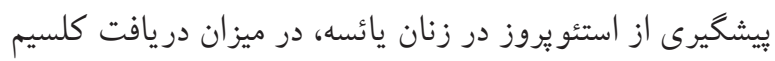

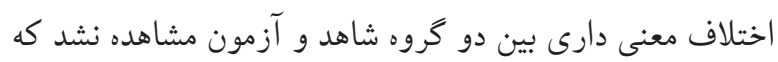

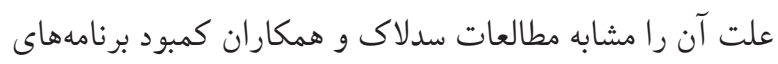
آموزشى بيان كردند. بيشتر آموزشهاى آنها سه جلسه يك ساعته ماته

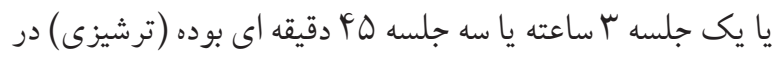

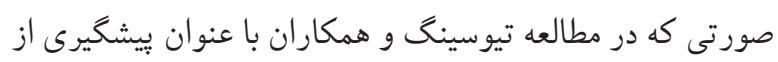

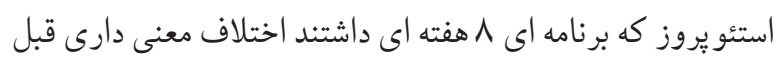

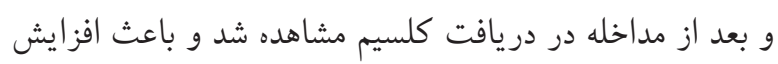
دريافت كلسيم شد. كه اين نتايج با مطالعه حاضر هم راستا مى باشد.

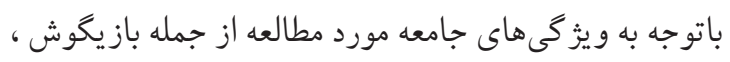


دوم ابتدايى هماند بازيكوشى، عدم توجه، حجب و حيا در سؤال

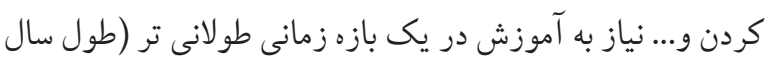

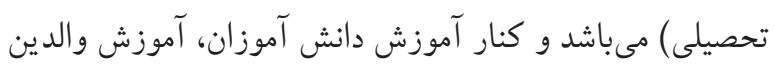

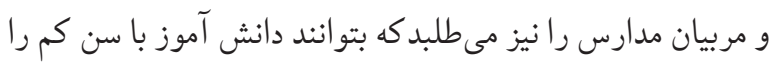

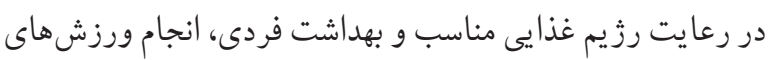
مناسب و بيشكيرى از فقر آهن حمايت كند. نتايج حاصل از اين مطالعه نشان مىدهد كه بين نمرات مت متغيرهاي

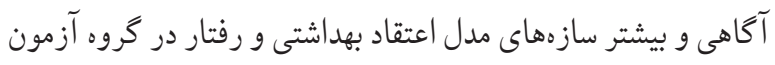

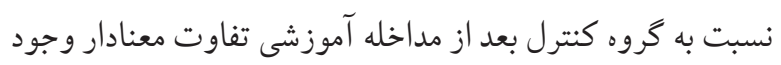

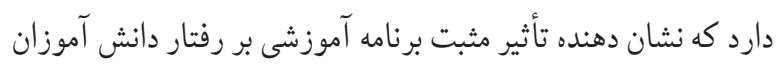

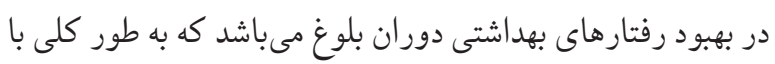

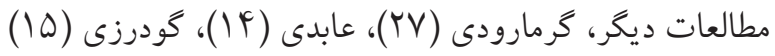
و شريفى راد (TN) هم راستا مى باشد.

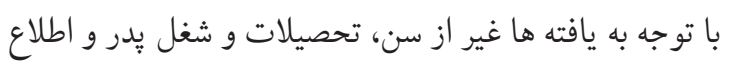

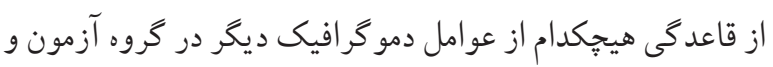

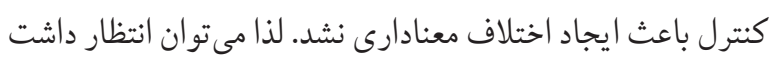

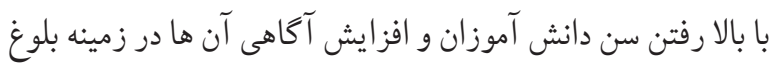

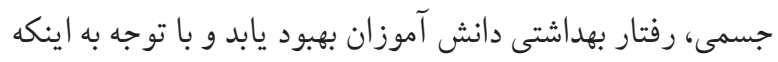

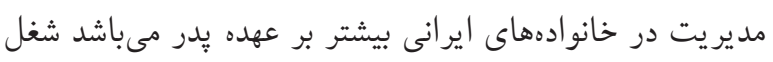

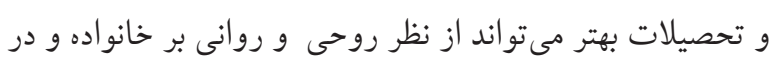

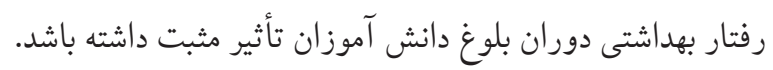

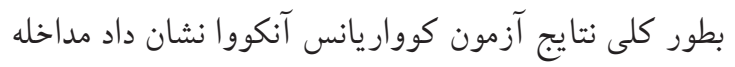

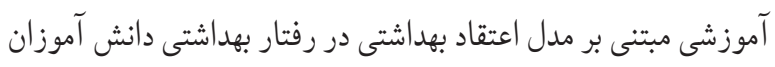

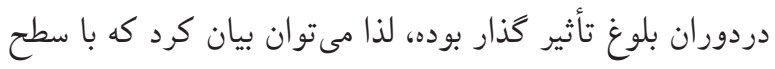

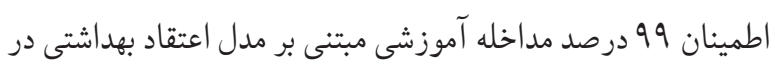

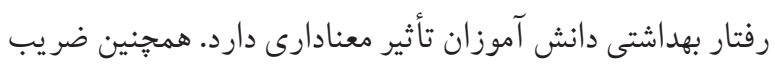

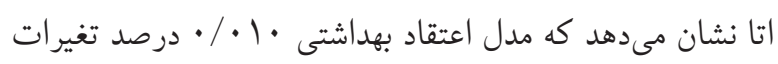
رفتار بهداشتى دانش آموزان را تببين مى كند.

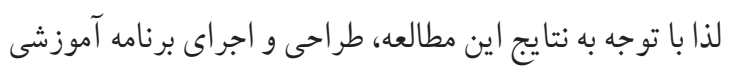

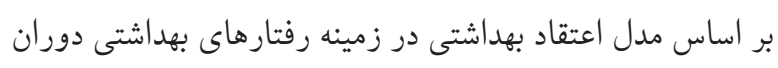

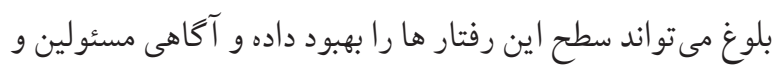

اين موضوع باعث شد كه بين نمره ميانكين راهنما براى عمل دانش

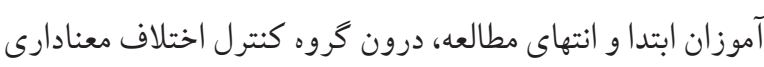

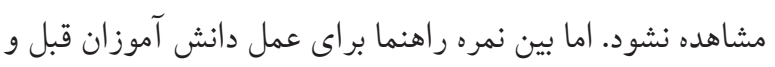

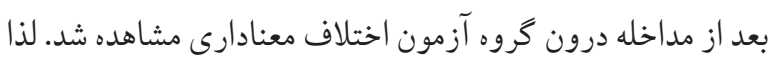

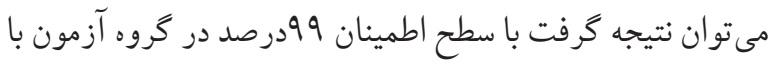

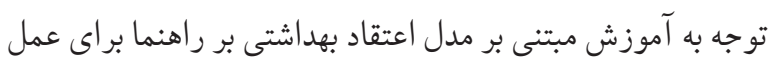

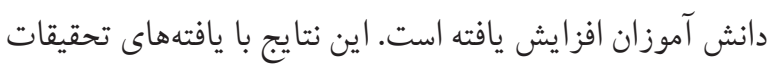

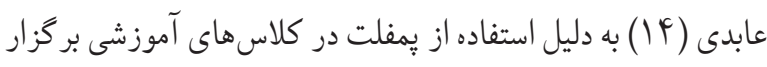

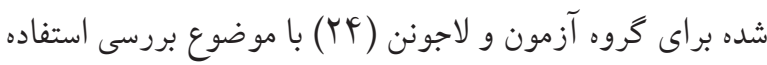

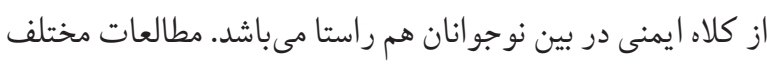

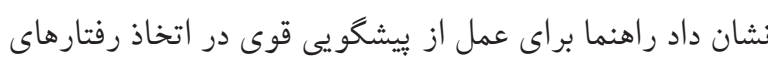

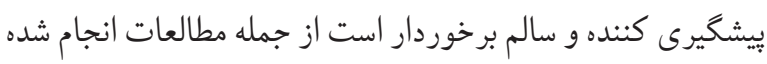
توسط لاجونن نشان داد كه راهنما براى عمل از ييشكويى قوى إنى

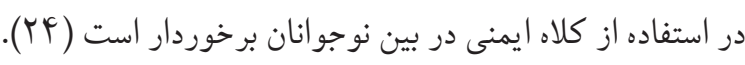

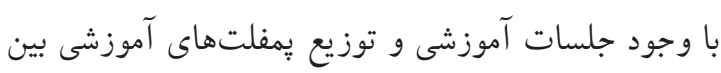

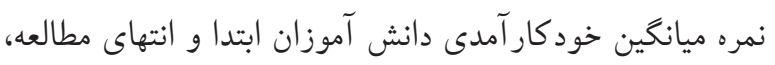

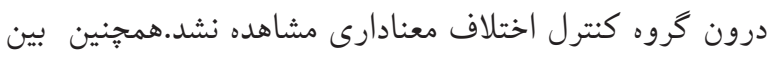

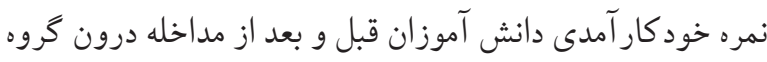

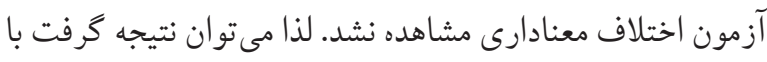

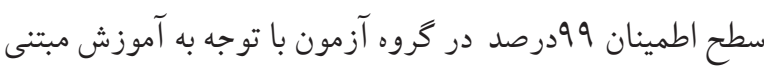

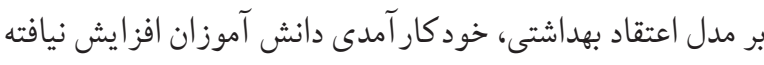

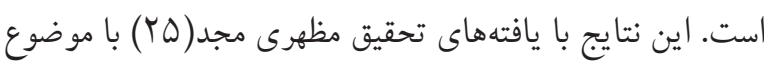

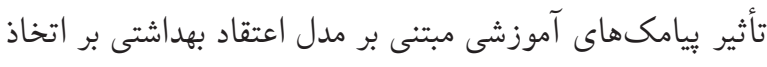

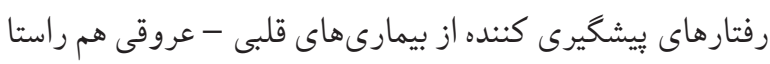

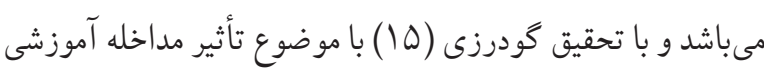

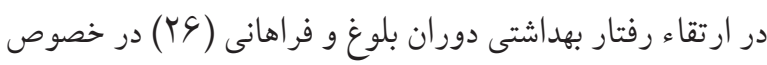

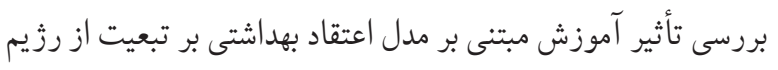

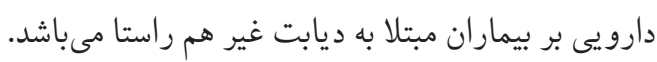

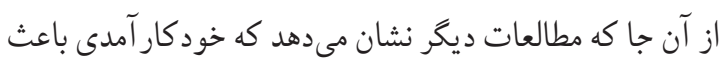

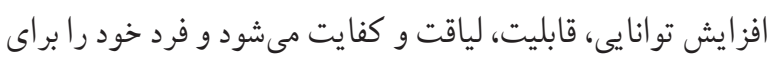

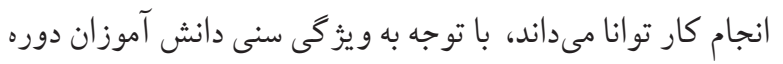


شده، موانع درك شده، راهنما براى عمل، رفتار در كروه آزمون

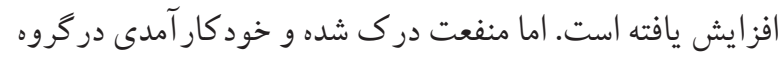

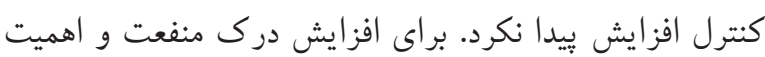
رعايت رفتارهاى بهداشتى دوران بلوغ با توجه به ويثخى سنى إنى دانش آموزان دوره دوم ابتدايى مواردى مثل عدم توجه، حيا و....

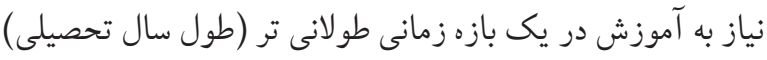

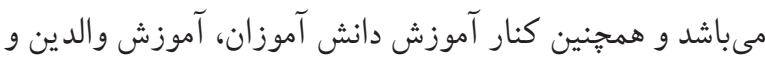

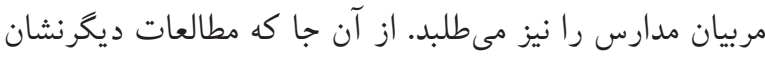

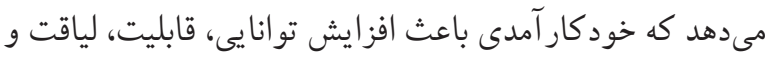

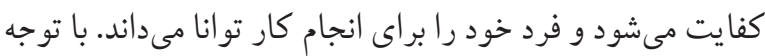

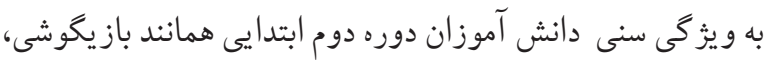

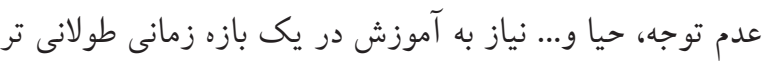

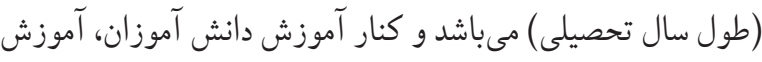

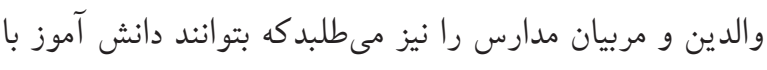
سن كم را در رعايت رزيم غذايى مناسب وبهداشت فردى، انجام

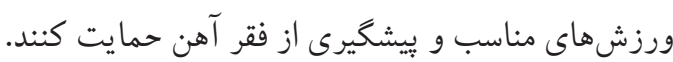

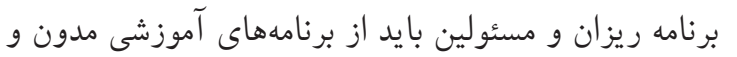

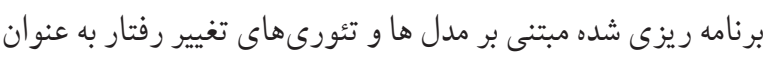

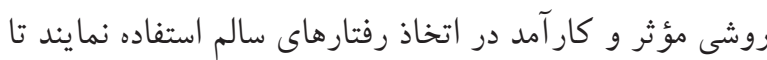

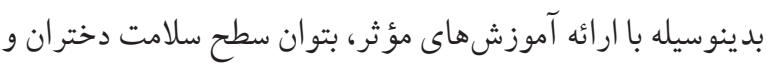

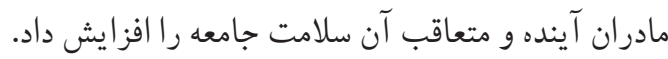

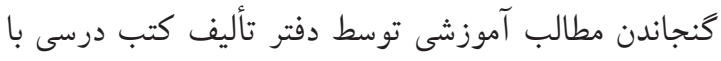

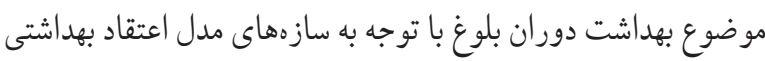

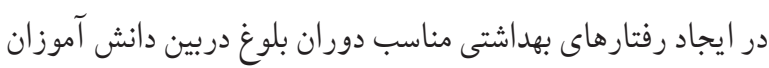
دوره دوم ابتدايى مؤثر مى باشد.

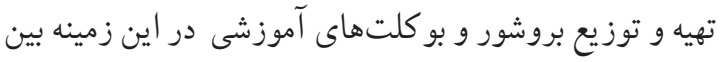

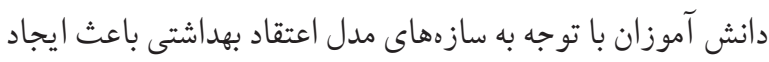

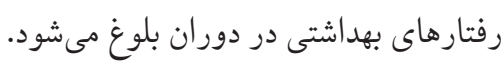

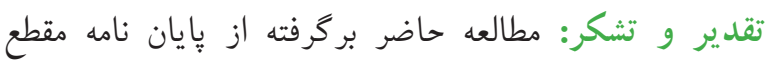
كارشناسى ارشد، رشته آموزش بهداشت مصوبه كميته اخلاق يُّوهش دانشكاه آزاد اسلامى، واحد علوم وتحقيقات به شناسه
مديران و برنامه ريزان آموزش و يرورش از اهميت و تأثير برنامه

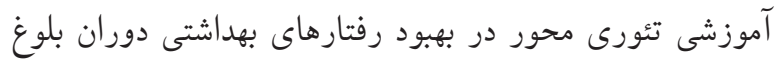

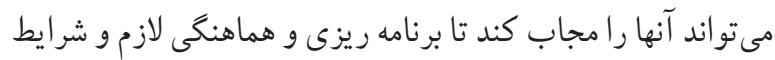

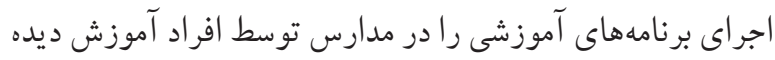

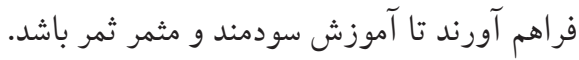
محدوديت اين مطالعه شامل: مشكل بودن هماهنكى جلسات

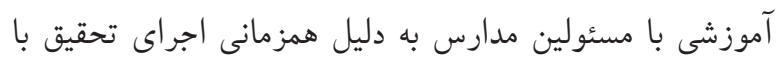

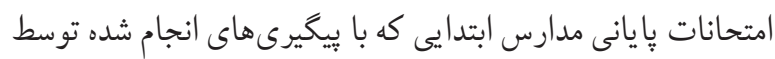

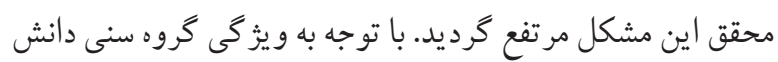

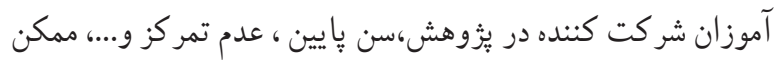

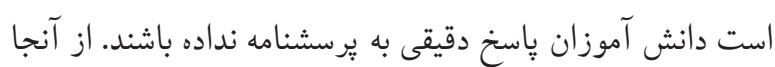

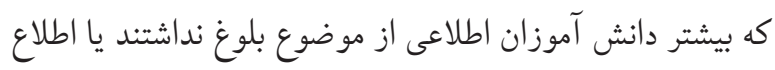

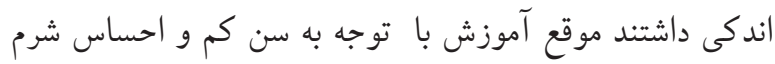

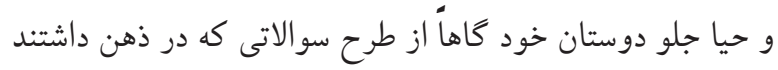

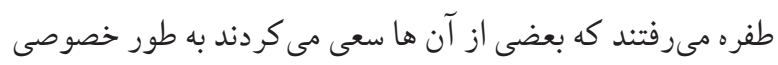

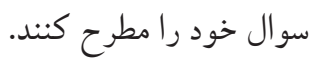
نتيجه گيرى: با توجه به يافته ها و نكاه به هريك از سازه ها و و درصد بيشرفت و تغييرات مشاهده شده مىتوان نتيجه كرفت كه مداخله آموزشى مبتنى بر مدل اعتقاد بهداشتى بر رفتارهات

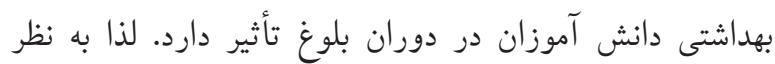

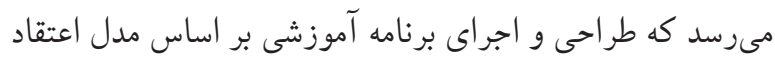

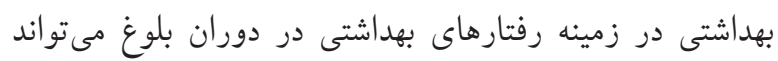
سطح اين رفتار ها را بهبود دهد. نتايج اين مطالعه نشان دهنده ارزش مدل اعتقاد بهداشتى در طراحى برنامهاى مداخله اى مؤثر براى تغيير رفتار بهداشتى است، جون اين مدل به لحاظ دارا بودن سازههاى حساسيت درك شدها،

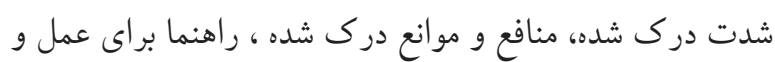

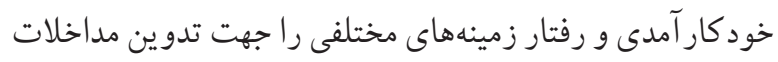

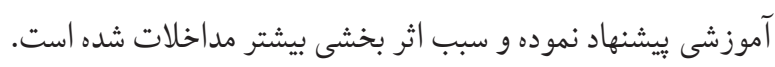
به طور كلى با اجراى مداخله آموزشى مبتنى بر مدل اعتقاد

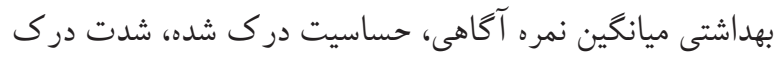


كننده در اين بُزوهش و آقاى دكتر بهرام فرد مشاور آمارى اين

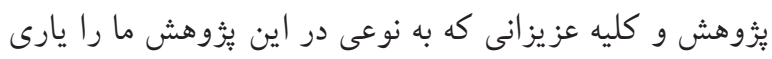
نمودند؛ كمال تشكر و قدردانى راداريم.

تعارض منافع: در اين مقاله هيج گونه تعارض منافعى وجود رداد

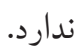

\section{References}

1. 1 zarrinkolah A, Dashti F, Abedi H, Masoudi SM. A Study of Puberty Health Literacy Level of the First 14-16 Year Girls Grade High School Students in the Eghlid City. Journal of Health Literacy. 2016;1(3):164-71. [DOI:10.22038/ jhl.2016.10964]

2. 2 Hoyt LT, Niu L, Pachucki MC, Chaku N. Timing of puberty in boys and girls: implications for population health. SSMpopulation health. 2020;10:100549. [DOI:10.1016/j. ssmph.2020.100549] [PMID] [PMCID]

3. 3 Ebrahimi F, Aghamolaei T, Abedini S, Rafati S. Effect of Educational Intervention Using Mobile on Life Style of Women Who Referred to Health Centers in Bandar Abbas. Iranian Journal of Health Education and Health Promotion. 2017;5(2):81-9. [DOI:10.30699/acadpub.ijhehp.5.2.81]

4. 4 Alimohammadi M, Samani LN. The Effects of MultimediaBased Puberty Health Education on Male Students' SelfEsteem in the Middle School. International Journal of Community Based Nursing and Midwifery. 2019;7(2):109.

5. 5 Mohammad Alizadeh Charandabi S, Mirghafourvand M, Rahmani A, Seidi S, Saffari E, Mahini M, et al. The effect of software on knowledge and performance of teenage girls toward puberty hygiene: a randomized controlled trial. Iranian Journal of Medical Education. 2014; 14(2):110121.

6. 6 Khatirpasha S. Puberty Health Education and Female Students' Self-efficacy. Journal of Client-Cen-tered Nursing Care. 2019;5(4):231-8.

7. 7 Moodi M, Zamanipour N, Sharifirad G-R, Shahnazi H. Evaluating puberty health program effect on knowledge increase among female intermediate and high school students in Birjand, Iran. Journal of education and health promotion. 2013;2. [DOI:10.4103/2277-9531.120851] [PMID] [PMCID]

8. 8 Akhavan Karbasi SSM. Educational assessment about puberty health and efficacy face to fac education and platelet in increase theirs aknowledge in the girl's student. Iranian Journal of pediatrics; 2003; 13: 68-82

9. 9 Sedghi Sabet M, Hasavari F, Saied Fazel Poor IF. A Survey
اخلاق IR.IAU.SRB.REC.1398.014 است. نويسند أنان از تمامى متصديان محتر اين مطالعه، اعم از گروه آموزش بهداشت و ارتقاء سلامت دانشكده علوم و فناورىهاى يزشكى، معاونت يُزوهشى دانشكده علوم و فناورىهاى يزشكى، كميته اخلاق دانشعاه علوم و تحقيقات تهران، رياست آموزش و يرورش منطقه I ا و واحد بهداشت منطقه fl Iا، اولياء و دانش آموزان شركت

of Knowledge, Attitude, and Health Behaviour of Girl Studeuts about Puberty. Journal of Guilan University of Medical Sciences 2003; 12(47): 31-8

10. 10 Olfati F, Aligholi S. A study on educational needs of teenage girls regarding the reproductive health and determination of proper strategies in achieving the target goals in Qazvin. Journal of Qazvin Uni Med Sci 2008; 12(2): 76-82.

11. 11 Crockett L, Deardorff J, Johnson M, Irwin C, Petersen AC. Puberty education in a global context: knowledge gaps, opportunities, and implications for policy. Journal of Research on Adolescence. 2019;29(1):177-95. [DOI:10.1111/jora.12452] [PMID]

12. 12 Kaplan EB. Women's perceptions of the adolescent experience. Adolescence. 1997;32(127):715.

13. 13 Whitehead D. A social cognitive model for health education/health promotion practice. Journal of Advanced Nursing. 2001;36(3):417-25. [DOI:10.1046/ j.1365-2648.2001.01973.x] [PMID]

14. 14 Vahedian-Shahroodi $M$, Tehrani $H$, Robat-Sarpooshi D, GHolian-Aval M, Jafari A, Alizadeh-Siuki $H$. The impact of health education on nutritional behaviors in female students: An application of health belief model. International Journal of Health Promotion and Education. 2019:1-13.. [DOI:10.1080/14635240.2019.1696219]

15. 15 Fisher JD, Fisher WA, Bryan AD, Misovich SJ. Information-motivation-behavioral skills model-based HIV risk behavior change intervention for inner-city high school youth. Health Psychology. 2002;21(2):177. [DOI:10.1037/0278-6133.21.2.177]

16. 16 Alizadeh Siuki H, Jadgal K, Shamaeian Razavi N, Zareban I, Heshmati H, Saghi N. Effects of Health Education Based on Health Belief Model on Nutrition Behaviors of Primary School Students in Torbat e Heydariyeh City in 2012. Journal of Health. 2015;5(4):289-99.

17. 17 Ahmadpour H, Mahri B, Shojaeezadeh D. The Effect of Nutrition Education in Pregnancy Based on Health Belief Model on Knowledge, Attitudes of Women Referring to 
Health Centers in Gonbad Kavoos. Journal of Neyshabur University of Medical Sciences, 2013; 3(2): 73-77

18. 18 Shojaezadeh D, Naeimi M, Noori K, Khalili Z, Haghverdi A. Survey of the effect of education based on the Health Belief Model (HBM) on knowledge, perception and performance about having breakfast of primary school student boys. Journal of Health. 2015;6(2):144-53.

19. 19 Sadeghi Sedeh B, Rabiei Z, Razavi H. Effects of health belief model components in general physicion rational prescribing of Chaharmahal va Bakhtiary province. Razi Journal of Medical Sciences. 2015;21(128):37-46.

20. 20 Torshizi L, Anooshehm, Ghofranipour, Ahmadi F, Hooshirarad A. Effect of Education Based on Health Belief Model on Osteoporosis Prevention in Postmenopausal Women. Journal of Nursing, 2009; 22(59): 98-102

21. 21 Karimi M, Ghofranipor F, Heidarnia A. The effect of health education based on health belief model on preventive actions of AIDS on addict in Zarandieh. Journal of Guilan University of Medical Sciences. 2009;18(70):6473.

22. 22 Hazavehei S, Taghdisi M, Saidi M. Application of the Health Belief Model for osteoporosis prevention among middle school girl students, Garmsar, Iran. Education for health. 2007;20(1):23.

23. 23 Hallberg U, Camling E, Zickert I, Robertson A, Berggren $U$. Dental appointment no shows: why do some parents fail to take their children to the dentist? international journal of paediatric dentistry; 2008; 18(1): 27-34.
24. 24 Lajunen T, Rasanen M. Can social psychological models be used to promote bicycle helmet use among teenagers? A comparison of the Health Belief Model, Theory of Planned Behavior and the Locus of Control. Journal of Safety Research; 2004; 35(1):23-115. [DOI:10.1016/j. jsr.2003.09.020] [PMID]

25. 25 Sharifzadeh G, Moodi M, AliAbadi H. The impact of the education based on health belief model on preventive behaviors of Crimean-Congo haemorrhagic fever among rural women from the city of Sarbishe. Journal of Health Sciences and Technology. 2017;1(1):23-9.

26. 26 Farahani F. The Effect of Education Based on Health Belief Model on Adherence to Diet in Patients with Diabetes, Shahid Beheshti University of Medical Sciences, 2016; 18)2): 110-112

27. 27 Gorramoodi Gh. Ashkaran, The Effect of an Educational Intervention Based on the Health Belief Model on the Prevention of Domestic Violence in Secondary School Students of Tehran. Journal of Nursing, 2016; 9(1): 32-3

28. 28 Sharifi R, Hazavi M, Hassanzadeh S. The Effect of Health Education Based on the Health Belief Model on Preventive Measures of Smoking in High School Students. Journal of Rawvarvand Danesh, Arak University of Medical Sciences, 2007; 1(10): 69-72

29. 29 Shirzadi S. et al. The Effect of Education Based on Health Belief Model on Physical Maturity Promotion of Adolescent Girls in Wellness Centers in Tehran. Journal of Education and Community Health, 2014; 1(4): 30-35 